This PDF is a selection from a published volume from the National Bureau of Economic Research

Volume Title: The Decline of Latin American Economies:

Growth, Institutions, and Crises

Volume Author/Editor: Sebastian Edwards, Gerardo Esquivel and Graciela Márquez, editors

Volume Publisher: University of Chicago Press

Volume ISBN: 0-226-18500-1

Volume URL: http://www.nber.org/books/edwa04-1

Conference Date: December 2-4, 2004

Publication Date: July 2007

Title: Sudden Stops and Currency Drops: A Historical Look

Author: Luis A. V. Catão

URL: http://www.nber.org/chapters/c10658 


\title{
Sudden Stops and Currency Drops A Historical Look
}

\author{
Luis A. V. Catão
}

\subsection{Introduction}

A prominent strand of international macroeconomics literature has recently devoted considerable attention to what has been dubbed "sudden stops"; that is, sharp reversals in aggregate foreign capital inflows. While there seems to be insufficient consensus on what triggers such reversals, two consequences have been amply documented - namely, exchange rate drops and downturns in economic activity, effectively constricting domestic consumption smoothing. This literature also notes, however, that not all countries respond similarly to sudden stops: whereas ensuing devaluations and output contractions are often dramatic among emerging markets, financially advanced countries tend to be far more impervious to those disruptive effects. ${ }^{1}$

These stylized facts about sudden stops have been based entirely on post-1970 evidence. Yet, periodical sharp reversals in international capital flows are not new phenomena. Leaving aside the period between the 1930s Depression and the breakdown of the Bretton-Woods system in 1971 (when stringent controls on cross-border capital flows prevailed around

Luis A. V. Catão is Senior Economist at the research department of the International Monetary Fund.

I thank my discussant, Lorenza Martínez, as well as Michael Bordo, Gian Maria MilesiFerretti, and participants of the 2004 NBER Inter-American Seminar in Economics for comments on an earlier draft. I am also grateful to George Kostelenos, Pedro Lains, Agustín Llona, Leandro Prados, Irving Stone, Bill Summerhill, Gail Triner, and Jeffrey Williamson for kindly sharing their data with me. The views expressed here are the author's alone and do not necessarily represent those of the IMF.

1. Calvo, Izquierdo, and Mejia (2004) note, for instance, that whereas 63 percent of sudden stop episodes have been associated with devaluations in emerging markets, the proportion drops to 17 percent among advanced economies. 
the globe), a large body of the historical literature has highlighted the fact that the pace of international capital flows has been anything but smooth (Eldstein 1982; Stone 1999; DeLong 1999; Eichengreen 2003). In particular, past financial crises in emerging economies have been shown to be frequently associated with dramatic downturns in capital flows that often seemed hard to rationalize (Kindleberger 1978). Partly because of data limitations, however, cross-country evidence on historical patterns of sudden stops and their relationship to exchange rate developments has been unsystematic at best.

This paper aims to fill some of this gap. First, it describes the historical evidence on sudden stops (SS henceforth) using a new international data set on capital inflows spanning sixteen countries since the early days of financial globalization, around 1870 - when asset market arbitrage was greatly spurred by the advent of the transatlantic telegraph in 1866through the eve of World War I. Two key features that underpin the current relevance of this period are the high degree of world capital market integration and the widespread use of bond financing as the main instrument of sovereign borrowing - two clear similarities with its late twentiethcentury/early twenty-first century counterpart. ${ }^{2}$

Four sets of questions are then asked about the nature of SSs, namely:

- Are SSs an exclusive feature of a class of countries, or do they hit capital-importing economies more generally, irrespective of their level of development and monetary regimes?

- How large are such SSs relative to the size of the recipient country's economy, and what is their average duration?

- Do SSs display some systematic cross-country pattern and time bunch, or is there evidence that they are typically triggered by idiosyncratic country shocks?

- Is there a systematic relationship between SSs and shifts in monetary policy and interest rates in major capital-exporting countries?

Against this background, the second contribution of the paper is to establish the links (if any) between SSs and currency crashes. A feature of the pre-World War I period, which makes it especially interesting for looking at this relationship, is the existence of an international monetary system that provided one key incentive for countries to peg their currencies to gold and thus forestall devaluations or depreciations. Bordo and Rockoff (1996) and Obstfeld and Taylor (2003) argue that membership of the "gold club" tended to shave off between 40 to 60 basis points in countries' spreads. This represented nonnegligible savings to sovereign borrowers, given the generally high ratios of countries' foreign-currency-denominated debts to GDP

2. See Obstfeld and Taylor (2004) for measures of international capital integration over the past century and a half. 
at the time, and the much narrower dispersion of country spreads relative to today (Mauro, Sussman, and Yafeh 2002). In this late nineteenth/ early twentieth-century setting, a currency drop following an SS would thus tend to be starkingly revealing about other costs of keeping the peg. As discussed subsequently, these costs include the need of accumulating large gold reserves yielding low returns (relative to other domestic investment opportunities) as well as forgoing the role of the exchange rate as a shock absorber. Further, decisions to abandon the peg or not to join gold may also be revealing of the existence of institutional frictions that mitigated the political cost of currency crises in some countries relative to others. ${ }^{3}$

To shed light on this relationship between SSs and currency drops, a central ingredient of the analysis is consideration given to the various factors that drive exchange rate behavior. Based on a simple model of nominal exchange rate determination and using probit panel regressions, the paper looks at what distinguishes successful peggers to those that experienced currency crashes. As will be seen, this approach helps discern countryspecific from common international factors driving the relationship between SSs and currency drops.

The remainder of the paper is structured as follows. Section 7.2 documents SS patterns across the sixteen countries comprising the study. Section 7.3 looks at the distinct exchange rate responses to capital account shocks in the context of a simple exchange rate model and probit regressions. Section 7.4 zooms in on country-specific monetary and fiscal stances as well as financial structures that may account for the different outcomes to common international shocks. Section 7.5 concludes with a summary of the main findings and a discussion of some salient implications.

\subsection{Patterns of Sudden Stops}

A first issue in the definition of an SS is whether capital inflows are measured in net or gross terms. The recent literature overwhelmingly uses the net concept - the capital or financial account balance - for which data is available at higher (usually quarterly) frequencies. ${ }^{4}$ However, this choice is not inconsequential. For instance, straightforward balance of payments

3. For instance, if interest groups linked to export sectors have a higher leverage on domestic policymaking in some of these countries, this would tend to mitigate such political costs and foster the politics of a weaker currency, delaying or even thwarting efforts to join or rejoin gold. There is considerable controversy in the literature, however, on whether such export lobbies systematically succeeded in shaping currency policies in the various countries during the late nineteenth and early twentieth centuries. See, for instance, Fritsch (1988) on the case of Brazil. Using a broader cross-country sample, Meissner (2005) finds no significant econometric evidence that inflationist agricultural interests played a significant role in the timing of gold pegs.

4. See, e.g., Dornbush, Goldfajn, and Valdez (1995), Edwards (2004), and Calvo, Izquierdo and Mejia (2004). One study that considers both gross and net flow variables is Caballero, Cowan, and Kearns (2004). 
(BOP) accounting indicates that an exogenous improvement in a country's net barter terms of trade automatically translates in a drop in net capital inflows, all else being constant. In an economic sense, this is very different from a situation in which the country faces a sudden drop in the supply of external financing, to which the current account has to improve (unless the country possesses sufficient international reserves to smoothe the capital account shock) through a devaluation or a contraction of income. In principle, the concept of sudden stops should refer to the latter and not to the former type of event.

In what follows, lack of data on total gross inflows for every country requires a somewhat eclectic approach. Specifically, I combine a measure of net capital inflows to countries for which the series is available, with information collected by Stone (1999) on gross portfolio calls on the London market. Since Britain was then by far the largest capital-exporting nation (in terms of both absolute annual flows and ratios to GNP) and the most important lending center for the overwhelming majority of emerging markets, one would expect such a portfolio call measure to closely trace fluctuations in gross flows to most countries. As shown below, information about SS patterns derived from these different sources yields a broadly consistent story.

Figure 7.1 plots net capital flows into capital importing countries for which data is available. ${ }^{5}$ As expected from countries with very different commodity specializations and under distinct policy regimes, there is clearly some diversity in the time pattern of capital inflows. Yet, what is arguably much more striking about figure 7.1 is the apparent synchronicity of the downswings across most countries. Three main episodes stand out in particular: the downswing of $1874-80$, that of the early 1890 s, and the shorter downturn of 1906-08. Clearly, not all countries were equally affected and, in a couple of occasions, foreign capital flows moved in opposite directions in a subset of them (e.g., Norway and Russia in the early 1890s). But overall, such downswings hit the overwhelming majority of countries at about the same time and were often abrupt. This suggests that pre-WWI SSs did display some time bunching similar to that observed over the past decade and a half (Calvo, Izquierdo, and Mejia 2004).

As discussed further, it is also striking that SSs hit countries with widely disparate per capita income levels and distinct monetary regimes. They struck countries as poor as Brazil (with an estimated per capita GDP of US\$811 in 1913 on constant 1990 purchasing power parity [PPP] basis) and as rich as the United States (with a per capital GDP of US $\$ 5,301$ on the same PPP basis in 1913). ${ }^{6}$ Some of them remained on

5. Net capital import data are not available for Greece and Portugal throughout the period, or for Argentina and Russia before the 1880s and Brazil after 1900. See appendix 2 for information on the respective data sources.

6. International data on per capita GDP on a constant PPP basis since 1870 is available in Maddison (2003). 
Latin America

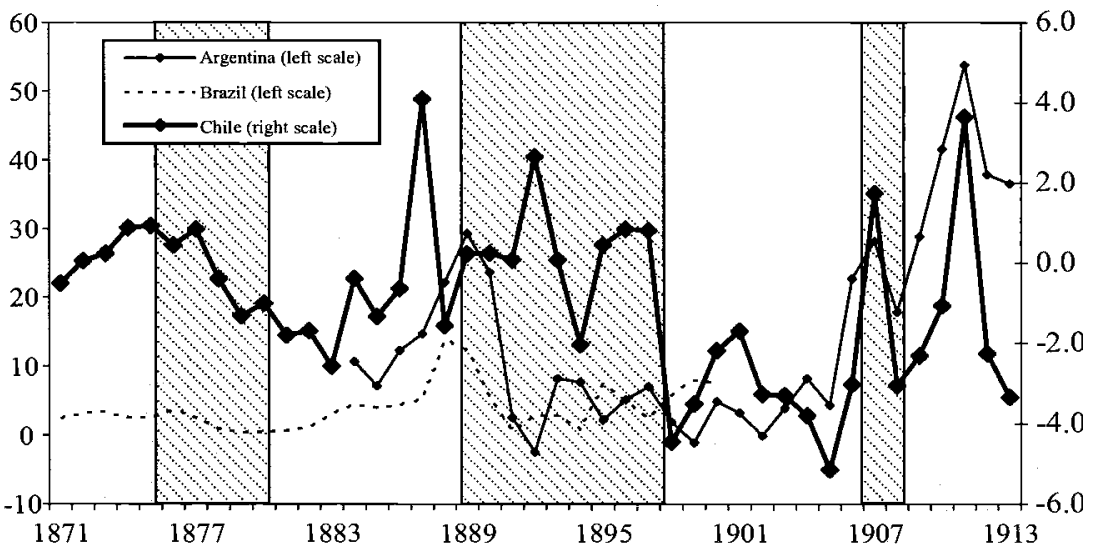

Peripheral Europe

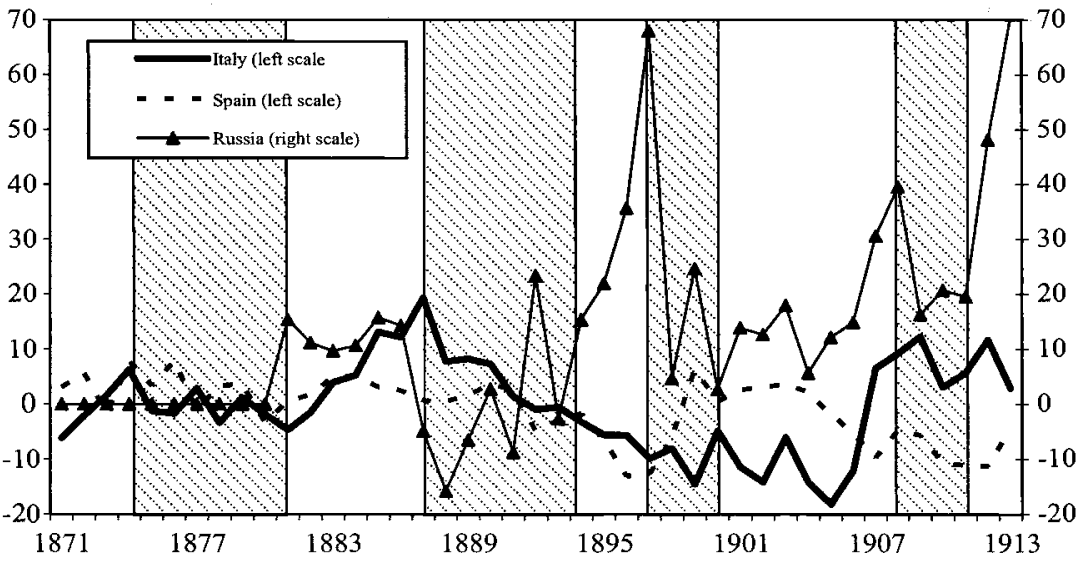

Fig. 7.1 Net foreign capital inflows (million pounds)

Source: See appendix B.

gold throughout, such as Scandinavia and North America since the late 1870 s, whereas others experimented with distinct monetary regimes such as bimetallism, temporary gold-pegs, and plain inconvertible paper money; none of these regimes could prevent a capital importer from being hit by an $\mathrm{SS}^{7}$

These inferences are broadly corroborated by available data on gross

7. It may well be that more flexible exchange rates helped insulate domestic output from the SS, as argued in Edwards (2004) based on post-1970 evidence. A comparison between output responses to SSs across the different exchange rate regimes in the prewar era is not discussed here, however, and constitutes an interesting topic for future research. 


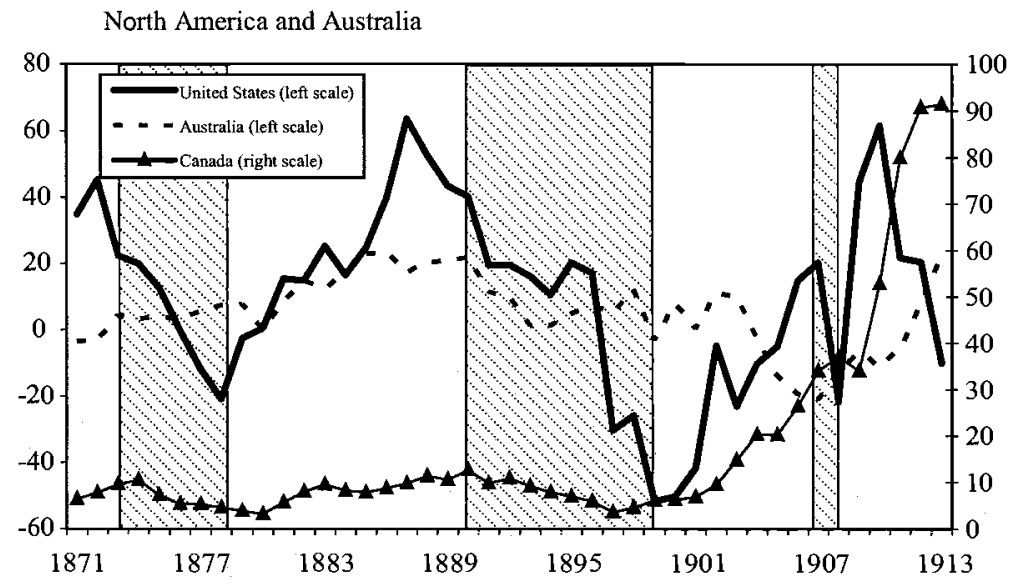

Scandinavia

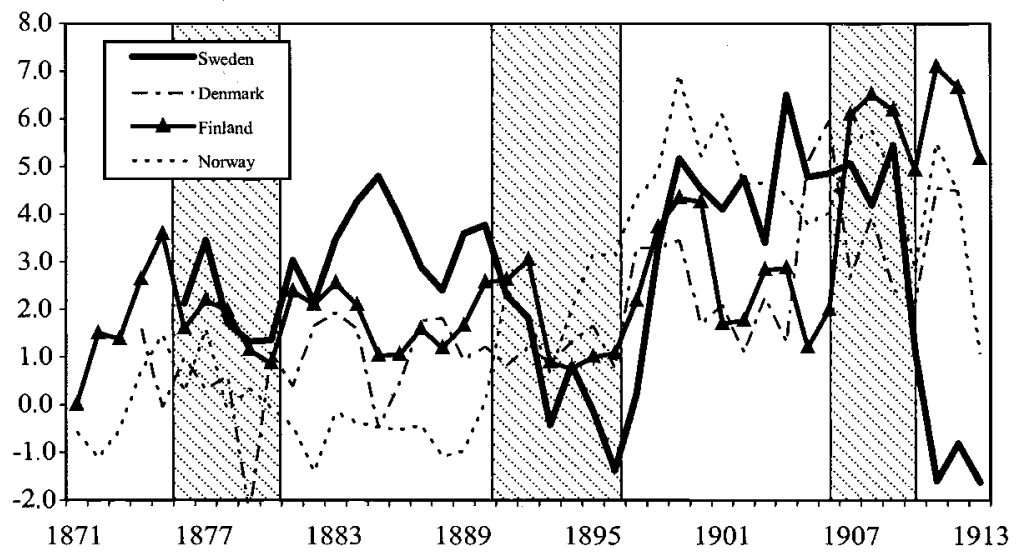

Fig. 7.1 (cont.)

flows based on portfolio calls on the London market. While the latter seem to account for a smaller share of total gross foreign investment in southern Europe and Russia - where French and German capital flows were prominent - bond flotations in London were by far the most important external financing instrument to capital-importing countries in Latin America and the Anglo-Saxon New World. Starting with Argentina, this gross inflow indicator portrays a very similar pattern as that of the net inflow data, both highlighting the major SS of 1889-1994, which was closely associated with a famed financial crisis that brought down the Baring's investment bank (see della Paolera and Taylor 2001 for a detailed account). Similarly, sharp downturns in gross portfolio inflows around the same period are also ob- 

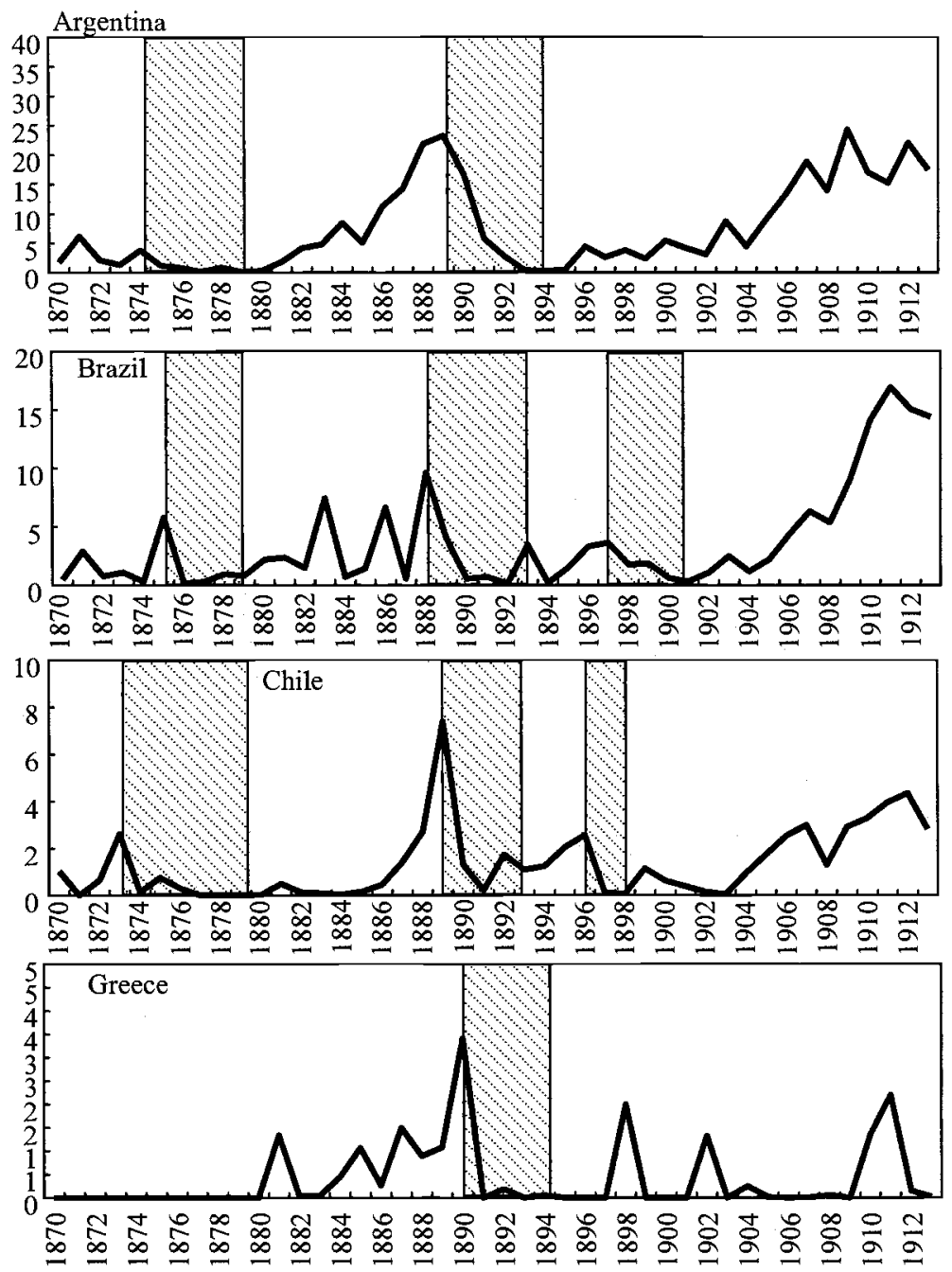

Fig. 7.2 Gross portfolio calls on London (million pounds)

Source: Stone (1999).

served for Brazil and Chile which, in addition, experienced another SS earlier in the 1870s and later in the 1890s - in the Brazilian case leading to a sovereign debt rescheduling in 1898 and in the Chilean case in an abandonment of the gold peg. ${ }^{8}$ With regard to southern Europe, and bearing in

8. For further specifics, see Franco (1990) and Llona Rodriguez (2000). 

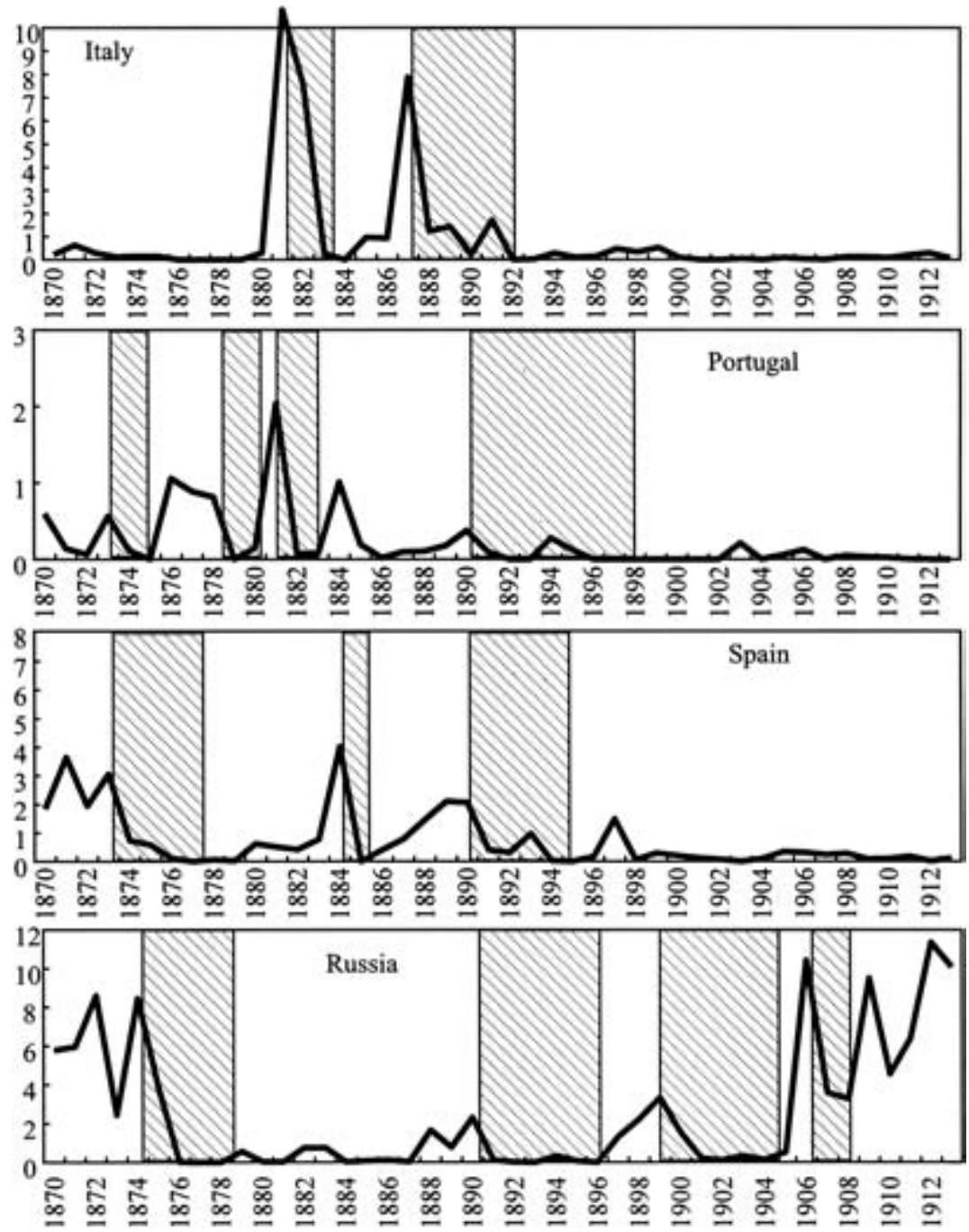

Fig. 7.2 (cont.)

mind the above-mentioned caveat about the limitations of gross flow data for these countries, figure 7.2 also fleshes out a similar timing of SSs in much of southern Europe. ${ }^{9}$

9. In the case of Russia, discrepancies in the timing of the SSs between the gross and the net capital inflow series plotted in figure 7.1 suggest that capital flows into Russia other than those associated with London floatations were important and may have dominated in the aggregate. Another possibility is that, since the net capital flow series was derived from the difference between the current account balance and changes in international reserves, it may reflect large inaccuracies in the measurement of these two variables. See appendix 2. 

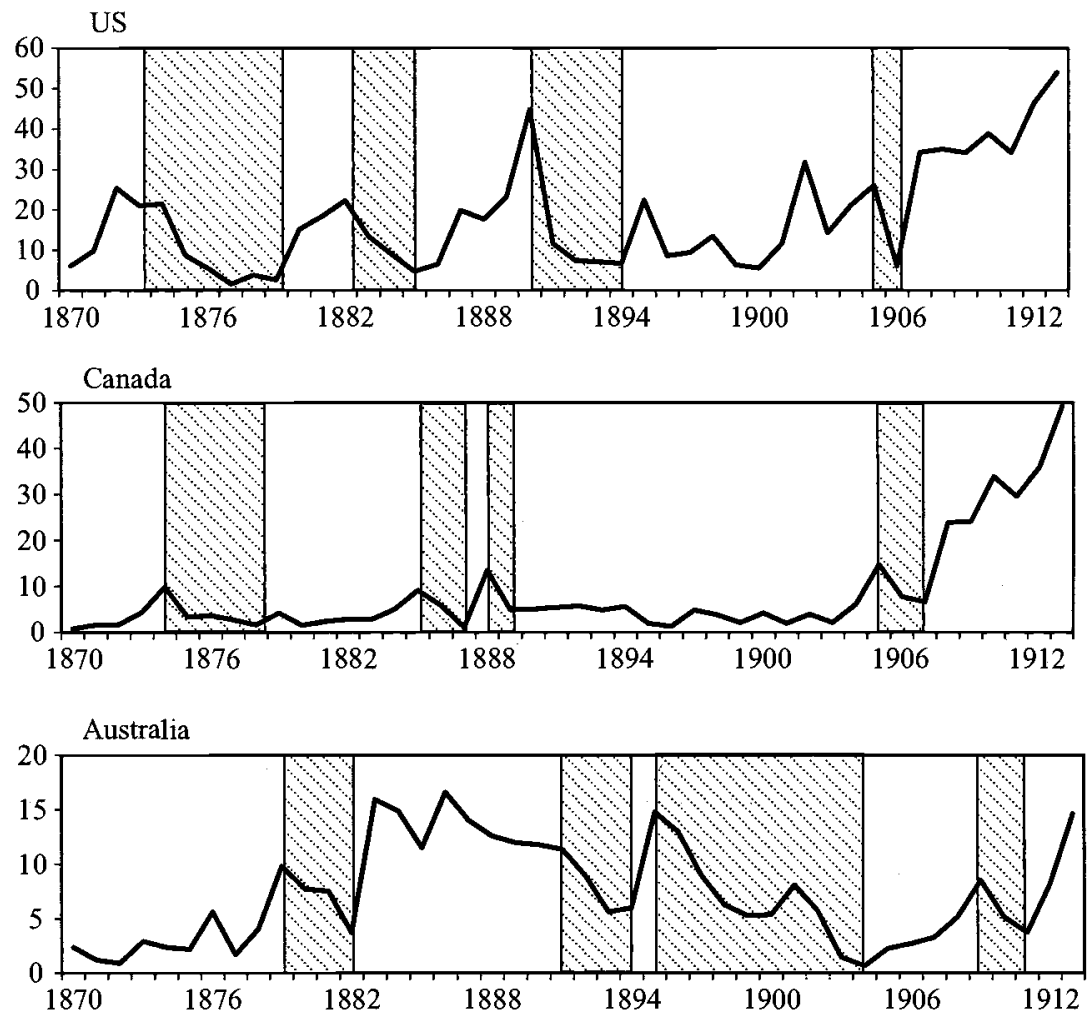

New Zealand

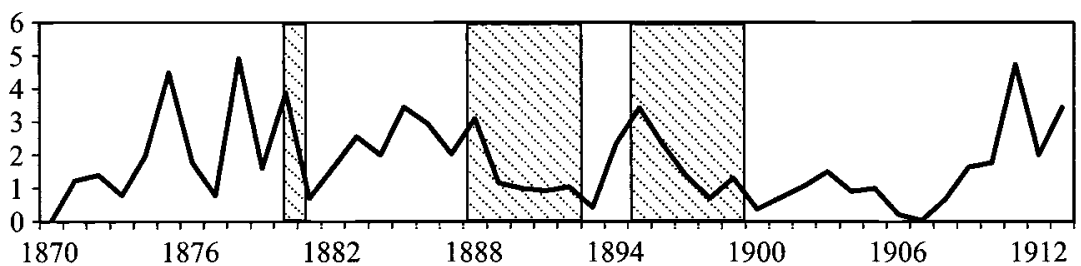

Fig. 7.2 (cont.)

Turning to the Anglo-Saxon capital importers, the gross capital inflows indicator further highlights the fact that these countries also experienced SSs, despite operating a more rules-based monetary regime, displaying greater fiscal discipline overall and remaining pegged to gold throughout. ${ }^{10}$

10. The United States formally adopted the gold standard in 1879 but policy actions and statements, as well as a gradual appreciation of the currency under way since the mid-1870s toward the antebellum parity, signaled to market participants that gold resumption was imminent. 


\begin{tabular}{|c|c|c|c|}
\hline & \multicolumn{2}{|c|}{ Sudden stops } & \multirow[b]{2}{*}{ Currency drops } \\
\hline & NKF definition & GKF definition & \\
\hline \multirow[t]{3}{*}{ Argentina } & & 1874-1879 & $1876-1878$ \\
\hline & 1889-1895 & 1889-1895 & $1885-1886$ \\
\hline & & & 1889-1891 \\
\hline \multirow[t]{2}{*}{ Brazil } & $1876-1880$ & $1875-1879$ & $1876-1880$ \\
\hline & 1888-1894 & 1888-1894 & $1890-1898$ \\
\hline \multirow[t]{5}{*}{ Chile } & $1875-1881$ & $1873-1880$ & $1876-1880$ \\
\hline & & & $1885-1886$ \\
\hline & 1891-1893 & 1889-1893 & 1891-1894 \\
\hline & 1897-1899 & $1896-1898$ & 1898-1899 \\
\hline & 1907-1908 & 1907-1908 & 1907-1908 \\
\hline \multirow[t]{2}{*}{ Greece } & & 1890-1897 & $1886-1887$ \\
\hline & & 1911-1913 & $1891-1895$ \\
\hline \multirow[t]{2}{*}{ Italy } & 1874-1881 & $1881-1884$ & \\
\hline & 1887-1899 & 1887-1892 & 1892-1894 \\
\hline \multirow[t]{5}{*}{ Portugal } & & $1873-1875$ & \\
\hline & & $1878-1880$ & \\
\hline & & 1884-1886 & \\
\hline & & $1890-1893$ & 1891-1898 \\
\hline & & & 1907-1908 \\
\hline \multirow[t]{4}{*}{ Spain } & $1876-1880$ & $1873-1877$ & \\
\hline & & 1884-1885 & \\
\hline & $1890-1896$ & 1889-1895 & $1892-1894$ \\
\hline & 1904-1907 & & 1897-1901 \\
\hline \multirow[t]{4}{*}{ Russia } & & $1874-1878$ & $1876-1878$ \\
\hline & $1885-1888$ & 1890-1992 & 1891-1892 \\
\hline & $1897-1900$ & 1899-1901 & \\
\hline & & 1906-1908 & \\
\hline \multirow[t]{3}{*}{ Australia } & 1890-1894 & $1886-1893$ & None \\
\hline & 1898-1899 & 1895-1899 & None \\
\hline & 1903-1907 & & None \\
\hline \multirow[t]{2}{*}{ Canada } & $1875-1880$ & $1874-1880$ & None \\
\hline & 1890-1897 & $1888-1896$ & None \\
\hline \multirow[t]{3}{*}{ Denmark } & $1875-1880$ & & None \\
\hline & 1884-1886 & & None \\
\hline & 1906-1908 & & None \\
\hline \multirow[t]{4}{*}{ Finland } & $1875-1880$ & & None \\
\hline & $1883-1885$ & & None \\
\hline & $1892-1894$ & & None \\
\hline & 1899-1901 & & None \\
\hline \multirow[t]{3}{*}{ New Zealand } & & $1888-1893$ & None \\
\hline & & 1895-1900 & None \\
\hline & & 1903-1907 & None \\
\hline Norway & 1899-1902 & & None \\
\hline \multirow[t]{2}{*}{ Sweden } & $1890-1893$ & & None \\
\hline & 1909-1913 & & None \\
\hline \multirow[t]{4}{*}{ United States } & $1872-1878$ & $1872-1877$ & None \\
\hline & 1887-1994 & $1890-1894$ & None \\
\hline & 1907-1908 & 1905-1906 & None \\
\hline & 1910-1913 & & None \\
\hline
\end{tabular}


Net Capital Flow Measure

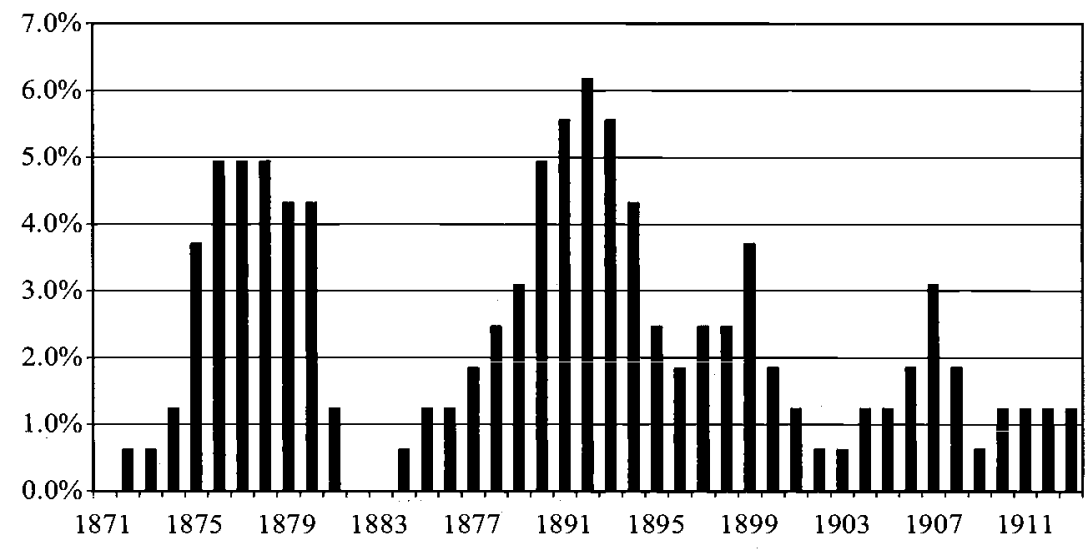

Gross Flow (London Portfolio Calls) Measure

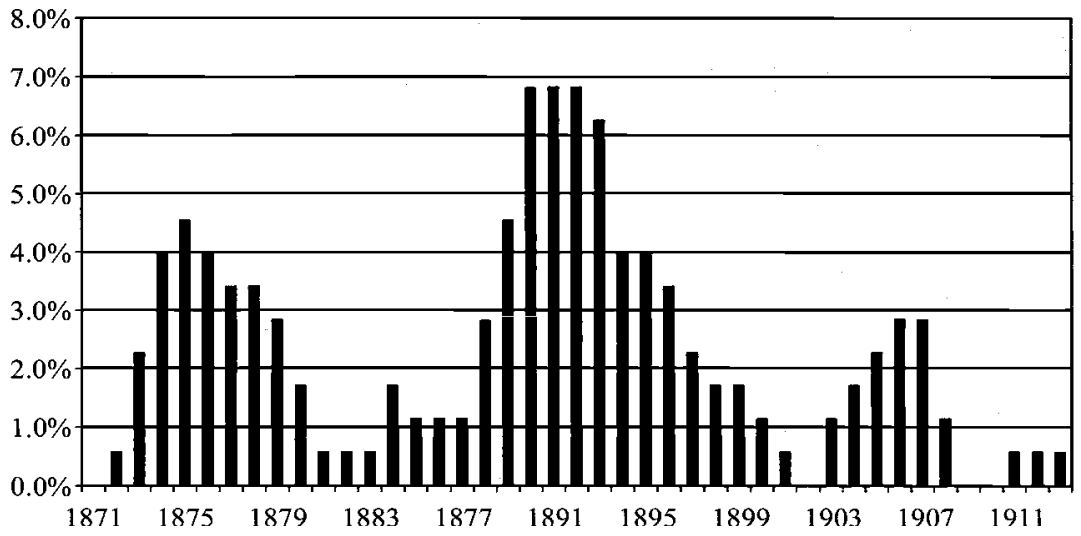

Fig. 7.3 Frequency distribution of sudden stops

Source: See appendix A.

Similar considerations apply to all four Scandinavian countries (Denmark, Finland, Norway, and Sweden). ${ }^{11}$

Further corroboration of the evidence that SSs usually bunch over time is provided in the more formal classification of these episodes, reported in

11. Fiscal discipline was especially remarkable among Scandinavian countries where public debt averaged between 15 to 20 percent of GDP during 1870-1913. On this front, Scandinavian countries were only superseded by the United States, for which the public debt to GDP ratio averaged 9 percent and fell to a low around 3 percent by the eve of World War I. This contrasts with much higher period averages for countries such as Argentina, Chile, Greece, Italy, Portugal, and Spain. The implications of these differences in fiscal performances are examined later. 
table 7.1. Although figures 7.1 and 7.2 make reasonably clear what episodes should qualify as SSs, table 7.1 summarizes this information, using the following working definition: an SS is defined as a drop (from peak to trough) of no less than two standard deviations of the deviations of respective series from a linear trend, and/or any drop that exceeds 3 percent of GDP over a period shorter than four years. Timing the beginning of SS as the year where capital inflows (measured in million pounds) peak, then SS is then said to end in the year when capital flows start rising relative to trend without falling back to its lowest level (also relative to trend) within a four-year window. On this basis, it is clear that both the net and the gross flow data yield a broadly similar picture about the timing of SSs in most countries.

Using the same definition, figure 7.3 plots the incidence of SSs over time, normalized by total SS observations in the sample. Both the net and gross measures clearly indicate that SSs bunched around the mid-1870s, the early 1890s, in 1906-1907, and also, albeit to a lesser extent, in the late 1890 s, according to the net flow measure. Such a pattern is consistent with that of the net capital outflow series from Britain, France, and Germany - the three main capital exporting countries of the late nineteenth century, which is plotted in the upper panel of figure 7.4. At the same time, the lower panel of the same figure also show that all SSs were, in turn, preceded with a one or two year lag by a hike in core central banks' discount rate. This has striking parallels with the more contemporary evidence on the adverse impact of advanced countries' monetary tightening on capital exports to emerging markets (Calvo, Leiderman, and Reinhart 1993; Fernandez-Arias 1996), indicating that exogenous monetary shocks were key drivers or "push factors" in capital flow reversals during the prewar period as well.

To further gauge the macroeconomic importance of SSs during the period, figure 7.5 plots the usual metric of scaling net capital flows by GDP. ${ }^{12}$ As one would expect in an era of free capital mobility and extensive international borrowing, figure 7.5 shows that fluctuations in net foreign capital inflows (NFKIs) were sizeable. Absolute annual deviations from a balanced capital account indicate that the macroeconomic impact was largest in Argentina (where such deviations averaged 10 percent of GDP over the entire period), then followed by Canada (7.5 percent of GDP), Finland (6.25 percent of GDP), and Australia (5.5 percent). Pooling together all SS events in countries for which the respective NFKI series is available, the peak-to-trough median drop in inflows amounted to 5.1 percent of GDP. This is of a very similar magnitude as the trough-to-peak magnitude of current account reversals identified by Calvo, Izquierdo, and

12. It would be useful, as suggested by Calvo, Izquierdo, and Mejia (2004), to use tradable sector output as a scaling factor if such information were available. 
Net Foreign Investment (million pounds)

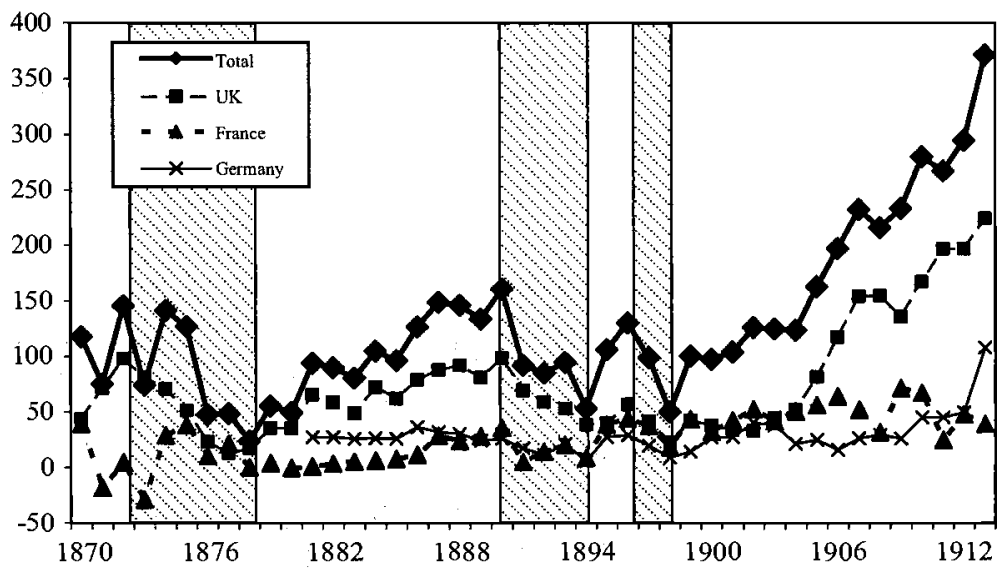

Central Bank Discount Rates (percent)

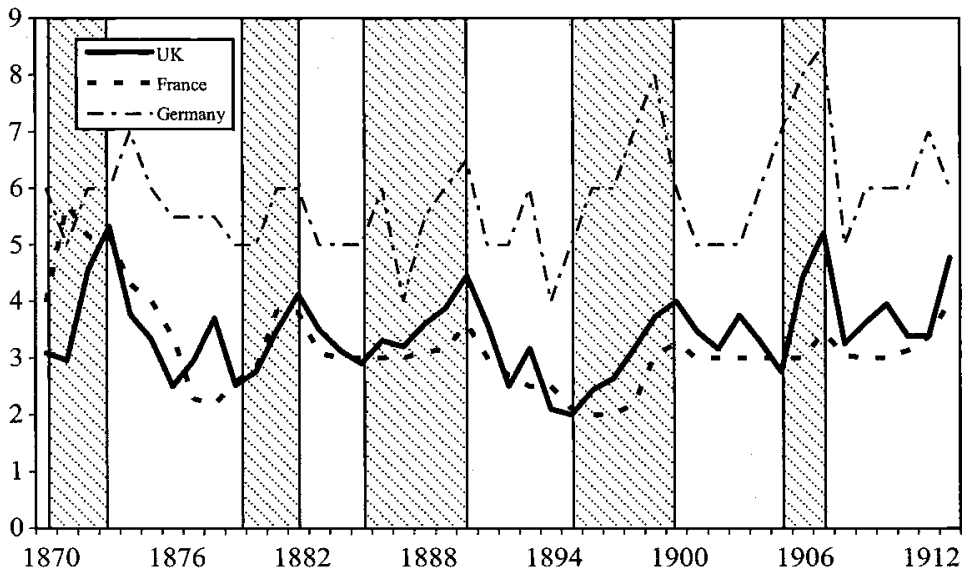

Fig. 7.4 Core countries: Net capital exports and interest rates (\%) Source: See appendix B.

Mejia 2004, appendix table 3) in the more recent vintage of SSs (4.9 percent). Further, as with its contemporary counterpart, pre-WWI SSs tended to be persistent: measured in terms of mean or median, and regardless of whether one uses the available gross or net capital inflow measures, the average duration of SSs is four years over the whole panel.

Also consistent with the prima facie evidence presented earlier, standard tests on mean differences in the magnitude of SSs (again measured from peak to trough) show no statistically significant difference between fixers 
Latin America

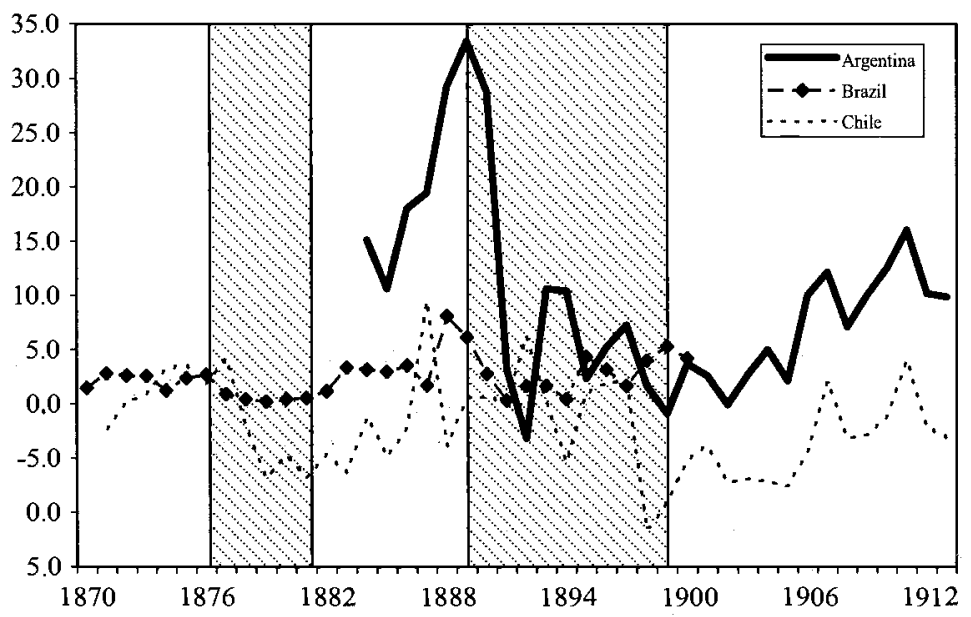

Europe

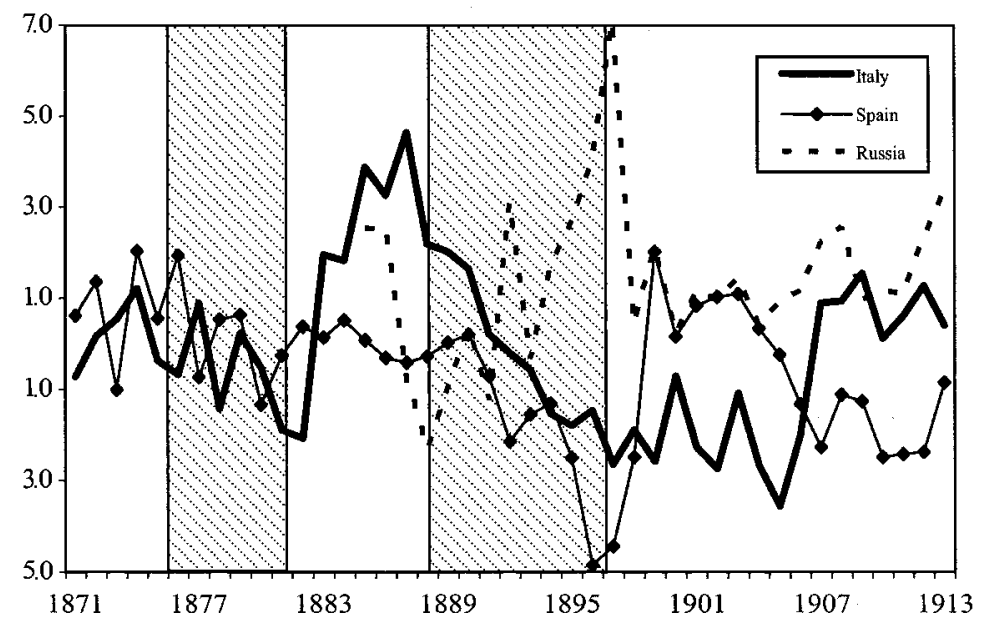

Fig. 7.5 Ratio of net capital inflows to GDP (\%)

Source: See Appendix A.

and floaters. ${ }^{13}$ No less interestingly, there is no statistically significant difference in the duration of SSs between the gold and nongold country groups: SSs are reasonably persistent in both cases, with mean durations

13. The mean for the floating (off-gold) group was 10.3 percent, whereas that for goldpeggers was 5.6, but this large mean difference results from one large outlier-Argentina in 1890-92. Dropping the latter, the mean for the off-gold group falls to 5.1 percent. Partly because of that outlier intragroup standard errors are large, at 12 and 3 percent. Not surpris- 
North America and Australia

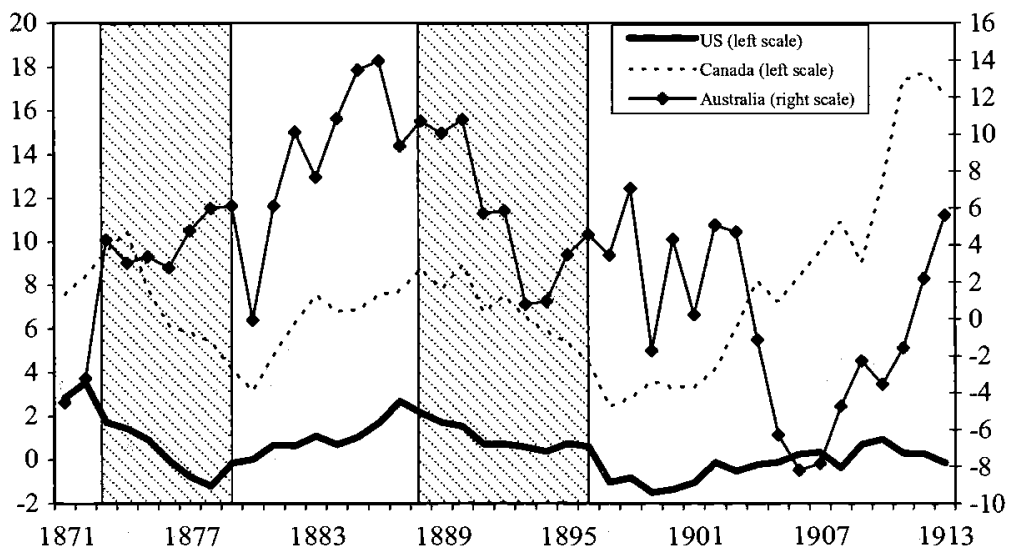

Scandinavia

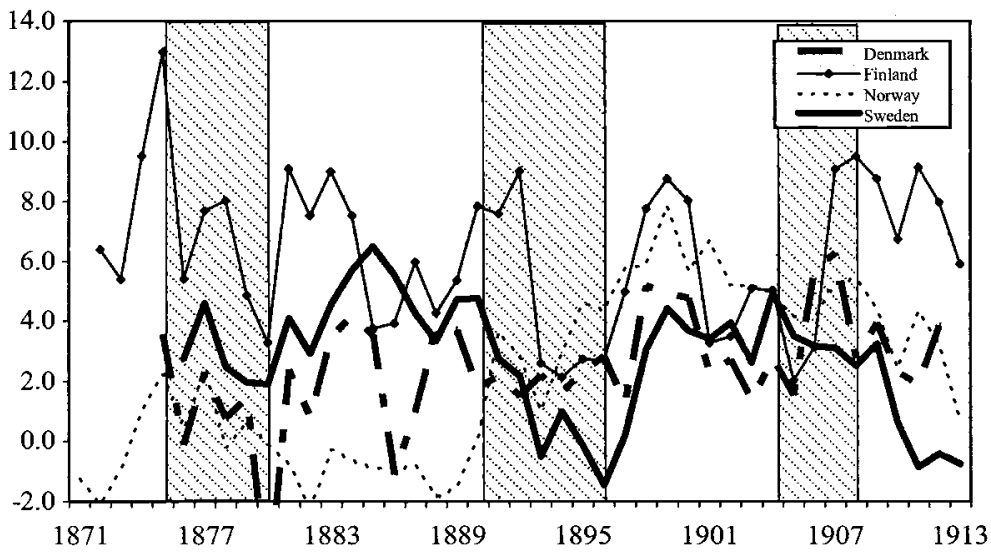

Fig. 7.5 (cont.)

of 3.7 and 4.2 years, respectively, and again with no statistically significant difference in means. ${ }^{14}$ This evidence calls into question the view that fixing the exchange rate was a sine qua non condition for attracting and/or stabilizing capital inflows. The fact that SSs also struck other gold-pegged countries with histories of sensible macropolicies suggests that neither the mon-

ingly in light of such high variance, the respective $z$-statistic for differences in mean is 0.99 , thus well below the 10 and 5 percent critical threshold levels of 1.64 and 1.96 .

14. The respective $z$-statistic is 0.69 . In computing this statistic, the duration of SSs in Greece, Portugal, and New Zealand (countries for which a NFKI series is unavoidable), as well as in Argentina and Russia prior to 1880, was measured using gross capital inflow series as reported in table 7.1. 
etary regime nor the fiscal policy stance can insulate a country from a capital account shock, an evidence with striking parallels to that amassed by Calvo, Izquierdo, and Mejia (2004) who find that neither differences in monetary regimes nor country-specific fiscal behavior can explain the incidence of SSs in their sample of 32 countries over 1990-2001.

\subsection{Capital Flows and Currency Crashes}

Despite the relatively rapid international spread of the gold standard from the 1870 s and the fact that all core industrial nations consistently pegged their currencies to gold until the eve of World War I, many capitalimporting countries continued to operate distinct monetary regimes during the period. In several cases what one observes is either a repeated switch between a gold peg and a floating regime (for instance, in Argentina, Brazil, Chile, and Greece), ${ }^{15}$ or countries that postponed gold standard membership until a later stage, once substantial gold reserves were accumulated, facilitating uninterrupted adherence to the peg, as in India, Japan, and Russia from 1897 (see Catão and Solomou 2005 for specifics). Within this wide spectrum of country-specific monetary arrangements, there were also those that never pegged to gold (China and Spain), one (Portugal) that adopted gold much earlier (1856) but also left earlier (1891), and countries such as Austria-Hungary and Italy, which were formally off-gold during much of the period but saw their national monetary authorities successfully shadowing the gold parity, which yielded relative exchange rate stability as a result.

This diversity is apparent in the behavior of the various spot exchange rates. While Anglo-Saxon and Scandinavian currencies were kept within the narrow gold points and thus were virtually flat, figure 7.6 shows how widely the price of the domestic currency relative to gold varied elsewhere. ${ }^{16}$ Among Latin American economies, not only did exchange rates display long-term depreciating trends, but they also witnessed large discrete downward adjustments in the mid-to-late 1870s and between the late 1880 s and early 1890s, which, in the case of Chile, was compounded a further downward adjustment in 1906-1908. Several European countries un-

15. Argentina stabilized its exchange rate and held on to a gold peg in 1870-75, 1883-84, and 1899-1913. Brazil was on gold for a few months between 1888 and 1889 and from 1906 to 1913. Chile was on a bimetallic standard through 1879 and on gold between 1895 and 1898 . Greece was on gold in 1885 and then in 1910-13.

16. Since the British pound was then the main international currency that adhered to a preestablished gold content throughout, all the nominal indices are measured relative to the pound. To facilitate comparison, all series are rebased to $1900=100$. Defining the exchange rate as the foreign price of domestic currency implies that a rise in the index corresponds to an appreciation of the respective national currency relative to the pound. The experience of countries that pegged their currencies to silver, such as Mexico, China, India and Japan, is not reviewed here but is examined in Catão and Solomou (2005). 
Latin America

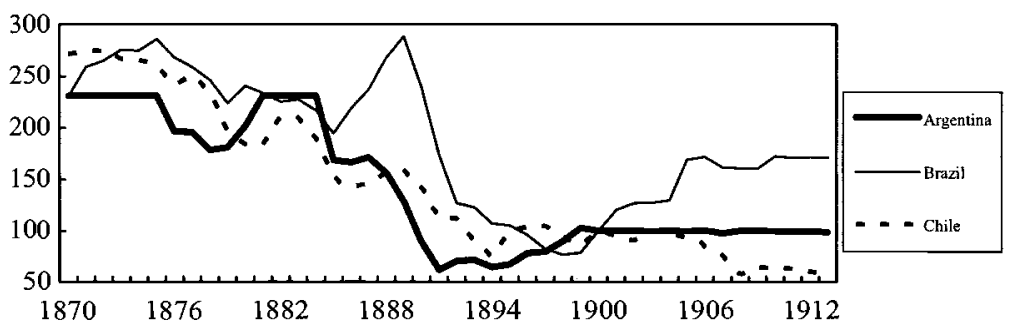

Europe

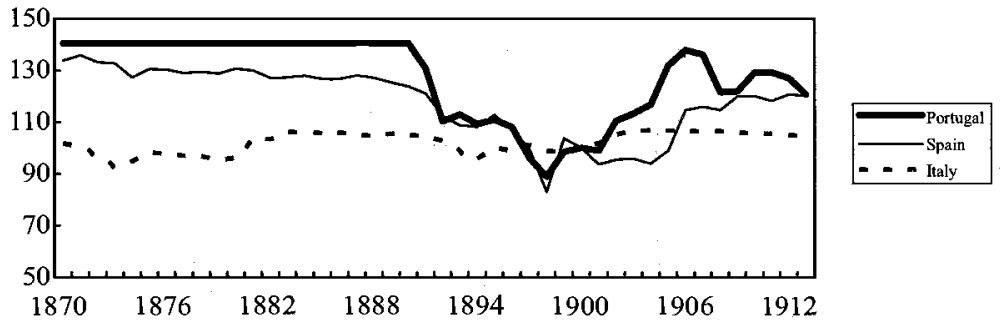

Europe (cont.)

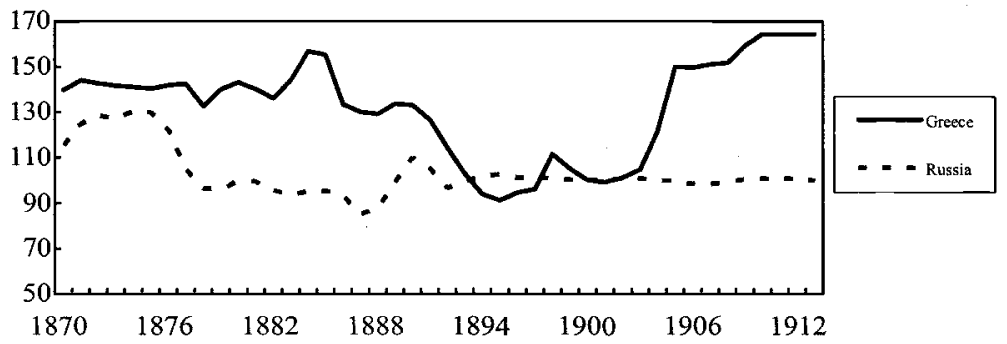

Fig. 7.6 Nominal exchange rates in currency crisis countries (pound sterling/ domestic currency, $1900=100$ )

der paper money regimes also witnessed nontrivial fluctuations in the gold parity of their currencies. Although relatively mild in Italy, sizeable depreciations are observed in Russia in 1875-78, Greece in both 1884-86 and 1890-95, Spain in 1890-93 and 1895-98, and Portugal in 1891-94. Comparing the timing of these various exchange rate drops or currency crash episodes with the timing of SSs in each countries reported in table 7.1, it is clear that currency crashes were either concomitant with SSs or followed the latter with a one- or two-year lag.

Three main questions then arise. First, to what extent are SSs driving these exchange rates relative to other factors? Second, is the causality running from SS to exchange rates or from exchange rate risk (driven by, say, 
contagion, or by factors that may be common to several countries, such as primary commodity terms of trade) to SSs? Third, why did some large capital exporters who also faced SSs managed to stick to the peg when others did not?

To shed light on these questions, one needs to consider the role of other potential explanatory variables in explaining the exchange rate as well as the possibility of reverse causality running from exchange rate changes to SSs. A useful starting point is a model of exchange rate determination that nests the various possible relationships - for instance, along the lines of the monetary models of the 1970s and 1980s, which allow for short-run price rigidity (see Frankel [1979] and Frankel and Rose [1995] for a synthesis). Appendix 1 shows how these earlier models can be straightforwardly extended to allow for a time-varying country risk premium - which becomes a function of the supply of international liquidity - and for violations to long-run PPP; instead, the real equilibrium exchange is let to be driven by terms of trade trends, long-run productivity differentials between home and abroad, and the country's fiscal position — consistent with a wide class of open-economy macromodels (see, for example, Edwards 1989, and Obstfeld and Rogoff 1996 for surveys).

The formal derivation of the model laid out in appendix 1 yields the following reduced-form equation for expected parity deviations of the spot exchange rate:

$$
\begin{aligned}
E\left(e_{t}-\bar{e}_{t}\right)= & \mu-\left(\Delta m_{t}-\rho \Delta y_{t}\right)+\alpha(t o t-\overline{t o t})_{t-1}+\varphi\left(\bar{y}_{p c}-\bar{y}_{p c}^{*}\right)_{t-1} \\
& -\eta\left(\frac{g}{t}-\frac{\bar{g}}{t}\right)_{t-1}+\frac{1}{\theta}\left(i_{t}-i_{t}^{*}\right)+v\left(\Delta b^{*}+\psi \Delta r e s\right)_{t}
\end{aligned}
$$

where tot stands for the respective country's net barter terms of trade; $m$ is domestic money supply, and $y$ for domestic real output; $y_{p c}$ and $y_{p c}^{*}$ stand for domestic and foreign per capita GDP respectively, and $i$ and $i^{*}$ for the short-term domestic and foreign interest rates; $g / t$ is the ratio of public expenditure to revenues; ${ }^{17} \Delta b^{*}$ stands for changes in the supply of foreign capital flows and $\Delta r e s$ for changes in the ratio of international reserves to paper currency in circulation. All variables are expressed in natural logarithms, with the bar subscript denoting the respective long-run or trend equilibrium levels.

Recalling that the exchange rate is defined here as the foreign price of the domestic currency, equation (1) states that the expectation of a currency drop will be higher as: (a) money supply grows relative to output; (b) terms of trade deteriorate relative to trend; (c) domestic productivity declines rel-

17. The ratio of fiscal expenditure $(G)$ to revenues $(T)$ is used instead of the more conventional of scaling $G-T$ by GDP for two reasons. One is that it is always a nonnegative number, which allows working with a log specification. Second, it circumvents the problem of the wellknown deficiencies of GDP data for many of the sample countries during the period. 


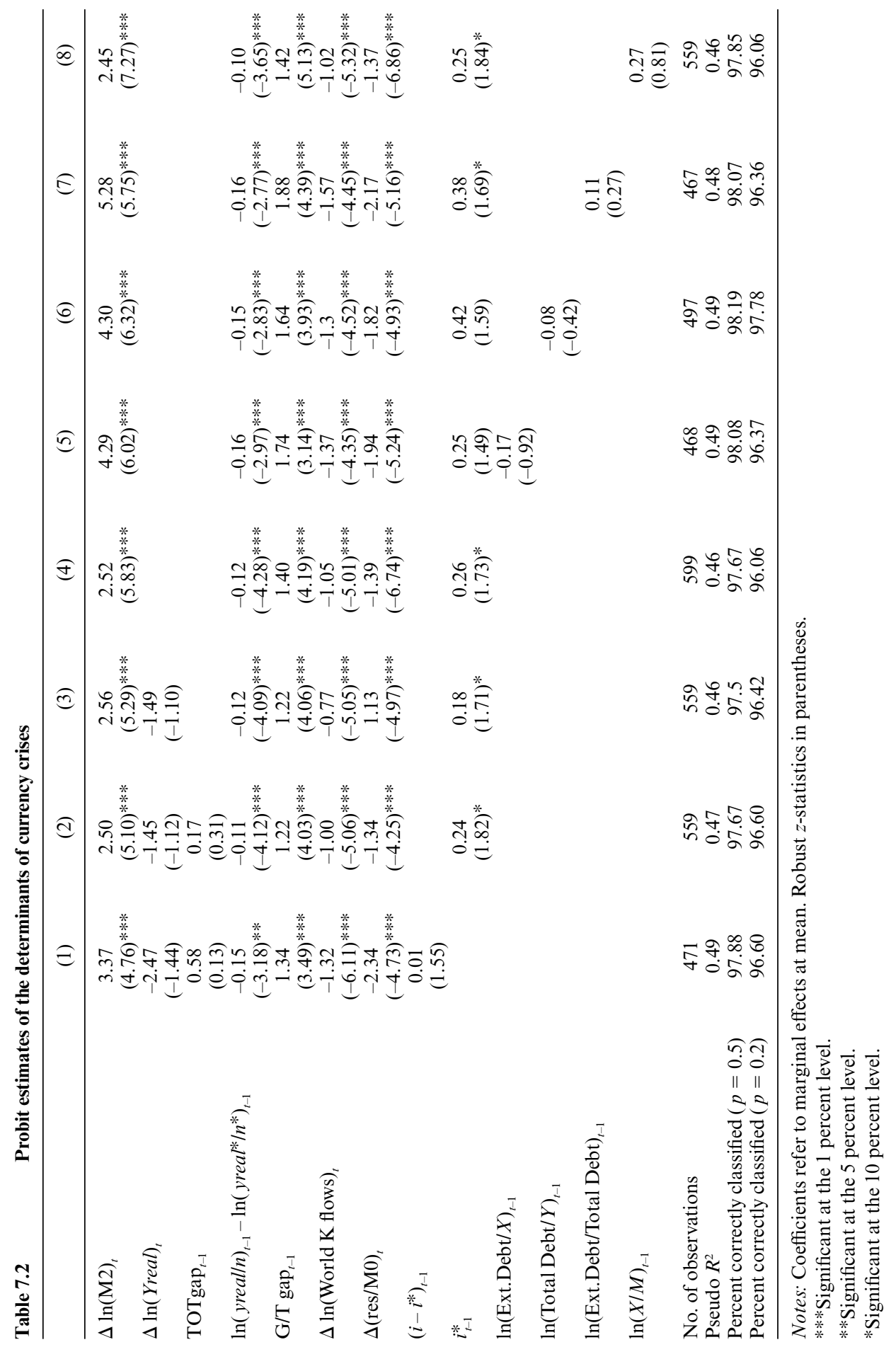


ative to foreign countries' productivity; (d) the domestic interest rate drops relative to its foreign counterpart; (e) the foreign supply of capital flows shifts down without the offsetting of rising reserves relative to the currency in circulation. It is straightforward to see in equation (1) that once the terms $1 / \theta\left(i_{t}-i_{t}^{*}\right)$ and $\psi \Delta$ res are shifted to the left-hand side, we have an index analogous to that of currency pressure popularized in the work of Eichengreen, Rose, and Wyplosz (1996). ${ }^{18}$

On the basis of that model, table 7.2 reports probit estimates of the determinants of a currency crash. In the absence of a commonly agreed-on criterion in the literature, ${ }^{19}$ a currency crash is defined here as an exchange rate depreciation greater than at least one standard deviation of the annual percentage change of the nominal exchange rate (relative to sterling) over the entire 1870-1913 period, provided that this depreciation is not fully reversed within a three-year window. Thus defined, our sample comprises nineteen such events, which are listed in table 7.1. ${ }^{20}$ As in Frankel and Rose (1996) and many others, the dependent variable is set to one in the first year of a crisis episode and zero otherwise; the observations pertaining to the period during which the crisis is ongoing (i.e., as the exchange continues to slide) are dropped, since they are part of the same crisis already counted once. Specifics on measurement and data sources are provided in appen$\operatorname{dix} 2$.

The first column of table 7.2 shows the estimates for the baseline model. Nearly all variables yield the sign predicted by theory and most of them are statistically significant at 1 percent. The exceptions are the terms of trade (TOT) gap (i.e., deviations of actual TOT from a log linear trend) ${ }_{,}^{21}$ output growth $(\Delta \ln [$ Yreal $])$, and the interest rate differential $\left(i-i^{*}\right)$. While the coefficient on output growth yields the correct sign, the interest rate differential indicator (which enters the regression with a one-year lag to mitigate endogeneity) actually yields the opposite sign as that predicted by the model-not an uncommon result in many empirical estimates of the uncovered interest parity condition (cf. Frankel and Rose 1995). Overall, the

18. An advantage of the present formulation is that the weights of the interest rate differential and the reserve terms can be econometrically determined through the estimation of $1 / \theta$ and $\psi$, rather than being imposed so as to equalize the respective unconditional variances as in Eichengreen, Rose, and Wyzplosz (1996).

19. See Frankel and Rose (1996), Kaminsky and Reinhart (1999), and Milesi-Ferretti and Razin (2000) for the different classification criteria employed in this literature. One feature of the pre-1914 period which helps minimize disagreements on crisis dates is the more stable price environment and the absence of policy devices such as crawling pegs, which make it harder to separate currency crashes from noncrisis related discrete exchange rate adjustments in response to high inflation bouts.

20. Due to lack of data on relevant covariates for Russia in the 1870 s, the effective number of crisis events is reduced to eighteen in the probit estimation.

21. Throughout this paper, detrending is made on a linear or log-linear time trend given evidence of trend stationarity from augmented Dickey-Fuller tests. These are available from the author upon request. 
coefficients show M2 growth to be a main determinant of currency crashes, with a 1 percentage point increase in the former increasing the likelihood of the latter by 3.4 percentage points. The other main drivers of currency risk are the ratio of government expenditure to revenues, measured relative to its log linear trend (G/T gap), and changes in the supply of foreign capital (World $\mathrm{K}$ flows), and net of changes in the reserve-to-currency ratio ("res/Mo"). The relative productivity differential is an additional significant predictor with the expected negative sign, though the estimated elasticity is a lot lower. Overall, the model fits the data reasonably well: a pseudo R-squared of about 0.5 is high relative to that found in similar studies and, more importantly, the model correctly predicts some 98 percent of events once a cutting-off point for refinancing a crash is of a predicted likelihood of greater than 50 percent. Employing a lower cut-off point of 20 percent reduces the prediction rate slightly, but even then the model correctly predicts 11 of the 18 crash events in the sample.

The two ensuing columns in table 7.2 fine tune the previous results by dropping the TOT (which had been statistically insignificant throughout), and replacing the interest rate differential variable by the foreign interest rate $i^{*}$, which is proxied by the Bank of England discount rate- the closest proxy to a short-run, risk-free rate during the period. Consistent with the prima facie evidence presented in section 7.2, higher foreign interest rates in the year prior to the currency crash had a positive and significant impact on the crash at 10 percent. This corroborates the finding that monetary tightening in the core is a significant driver of currency pressures in capital-importing countries. As also expected, given the evidence presented in section 7.2, the inclusion of $i^{*}$ lowers the estimated coefficients on both the capital flow and reserve variables. This is consistent with the results of Eichengreen (1992) who, using Granger-causality tests in a vector auto-regressive (VAR) model of the U.K. economy, finds that changes in the Bank of England discount rate Granger-caused capital exports. To the extent that the two other core European central banks in France and Germany tended to follow the Bank of England lead around cyclical turning points - as illustrated in the bottom panel of figure 7.4 and also noted in Lindert (1969) - the effect of hikes in the U.K. discount rate on net capital importing countries was thereby reinforced.

Finally, columns (5) to (8) check the robustness of the foregoing regressions to the inclusion of three other potentially important variables. One is the ratio of external public debt to exports - a usual yardstick of country solvency in the sovereign debt literature. The respective estimate is statistically insignificant and has the opposite sign as that postulated by theory. A similar finding obtains for the ratio of total public debt to GDP (column [6]). The following column reports results for the inclusion of the ratio of external to total public debt — an indicator of the extent of currency mismatches in countries' balance sheets that is commonly associated with the 
concept of original sin, that is, a country's incapacity to issue debt denominated in its own currency. This idea, much popularized by Eichengreen and Hausman (1999) and further elaborated in many subsequent contributions, suggests that the greater the mismatch the higher the risk of sovereign defaults and currency crashes; so, one would expect the coefficient on this variable to be positively signed. Column (7) of table 7.2 shows that while the respective point estimate is indeed positive it is small and not statistically different from zero. So, there is no evidence that currency denomination of the country's debt is a significant determinant of currency risk. Finally, the last column of table 7.2 gauges whether trade imbalances (defined as the log of export to import values) add any significant additional explanatory power to the regressions and help predict crash events. The estimates show that this does not seem the case, likely reflecting the fact that such imbalances are already captured by the other covariates in the model.

In short, the preceding econometric results indicate that fluctuations in international capital flows are significant determinants of currency risk. Accordingly, it is not surprising that SSs tend to be associated with currency crashes. Further, since SSs are often preceded by interest rate hikes in core countries, it thus appears that financial developments exogenous to net capital-importing countries are at the root of currency crises. Yet, this econometric evidence also indicates that this is not the full story: since not all countries respond similarly to those external shocks, country-specific factors do matter - notably the growth of money supply, the cyclicality of fiscal balances, and variations in the international reserve coverage of the domestic money stock. Each of these factors is discussed next.

\subsection{Domestic Financial Imperfections and Procyclical Behavior}

Two broad generalizations seem to command wide consensus in the historical literature on the financial markets of countries that witnessed currency crashes before WWI. ${ }^{22}$ One is that their financial markets were much shallower relative not only to the so-called European core (Britain, France, and Germany) but also relative to other emerging economies of the AngloSaxon world and Scandinavia. This can be unambiguously gauged by a broad range of financial development indicators such as the number of banks and bank capitalization per capita, or the ratios of broad money and domestic bank credit to GDP. In addition, banks in these economies were deemed to be poorly regulated, and information about borrowers' credit history usually hard to obtain. While these imperfections were in some

22. See, for instance, della Paolera and Taylor (2001) on Argentina; Goldsmith (1986), Haber (1997), and Trimer (2000) on Brazil; Llona Rodriguez (1990) on Chile; Fratianni and Spinelli (1997, children. 3) on Italy. 
cases mitigated by stringent controls restricting entry (as in Brazil, for instance), such regulations appear to have greatly hindered efficiency-a point stressed in Cameron's classic comparative study on early banking (Cameron 1972). To these structural features, one added ingredient in those economies was the existence of multiple issuing banks and the lack of a national bank holding the monopoly of fiduciary money and soundly performing the role of a lender of last resort..$^{23}$

Some salient implications follow. First, shallower domestic bond markets and limited access to bank credit by firms imply that borrowers were typically credit constrained; hence, any outward shift in the external supply of funds would tend to automatically translate into faster credit growth. Second, once information about creditworthiness is hard to obtain, lending becomes more responsive to current collateral values pledged against loans. Third, illiquid domestic markets would make it harder for banks to borrow from the local private sector or sell to others the illiquid (but otherwise solvent) items in their portfolios during monetary crunches, exacerbating the risk of fire sales and bank runs in the wake of SSs and business cycle downturns. Finally, the decentralization of note issuing rights combined with deficient regulations and governments that were dependent on banks to finance large deficits tended to exacerbate moral hazard and thus undermine the practice of backing of outstanding bank notes with safe levels of specie holdings. This was likely to heighten the depressing effects of money creation on the exchange rate.

Figure 7.7 shows that countries that experienced currency crashes were indeed the ones that embarked upon rapid monetary expansion, which far exceeded domestic income during cyclical upswings. Argentina is the most notable case, with the ratio of M2 to GDP rising from 28 to 65 percent of GDP between 1880-89, even though real GDP itself nearly tripled during the same period. The flip side of such a rapid monetary expansion was a sharp drop in the international reserve coverage of the domestic currency in the later stages of the boom, which left banks highly vulnerable to a run when capital flows dried up in the run-up to the Baring's crisis of 1890-91. Likewise in Brazil, where monetary expansion had been previously curbed by stringent regulations on bank entry, the sudden stop of 1890-91 was preceded by unprecedented monetary expansion resulting from the sudden lift of controls on bank issuance (the Encilhamento), leading to a twofold increase in the broad money to GDP ratio between 1889 and 1891.

Data for other countries is likewise suggestive of the significant role of

23. This seems to have been an important distinguishing feature of successful financial development in northern Europe. On the less well known but interesting experience of countries other than the European core and the United States, see the key role played by the Nationalbanken in Denmark, the Nederlandsche Bank in the Netherlands, and the Riksbank in Sweden which are discussed in Hansen (1991), Jonker (1997), and Jonung (1984), respectively. 

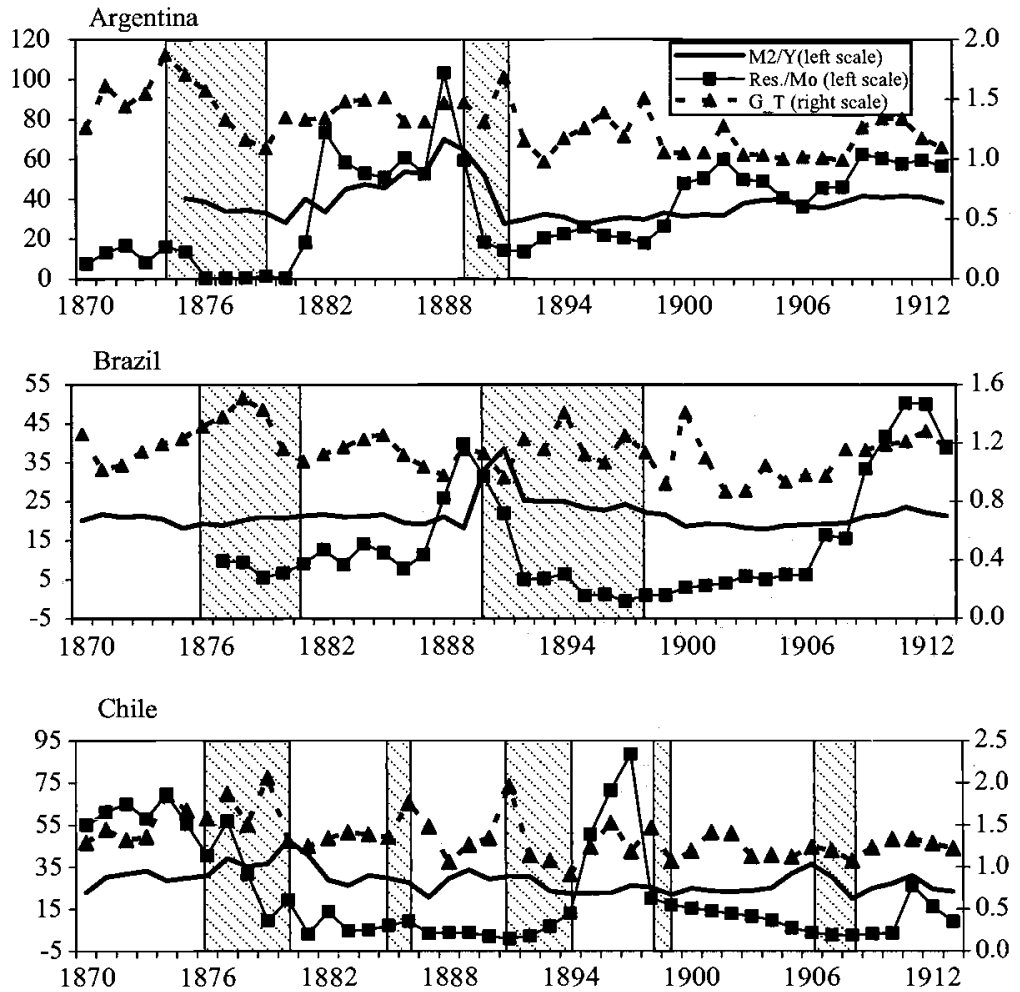

Greece

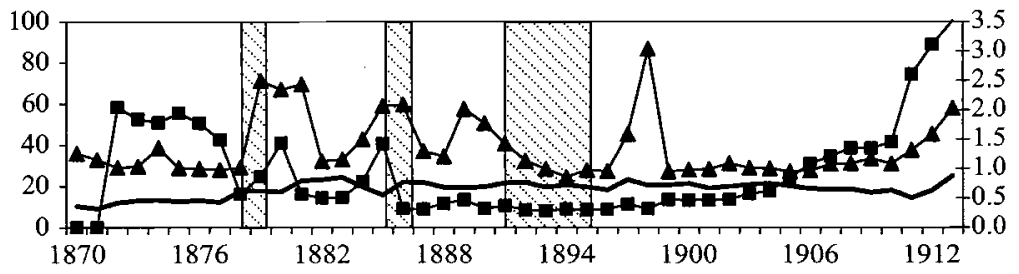

Fig. 7.7 Monetary and fiscal indicators in currency crisis countries (currency crashes in shaded areas)

Source: See appendix A.

monetary expansion in brewing currency crashes during SSs. In Chile, Portugal, and to a lesser degree Spain, the elasticity of broad money to income rose well above unity in the two to three years prior to the 1890-1892 crashes. This contrasts with the smoother behavior of money supply in other countries, which either managed to stick to the peg or that experienced a relatively mild depreciation, such as Italy and Russia in the early 1890s. Figure 7.8 corroborates the view that a high procyclicality of domestic bank credit, as proxied by the M2 multiplier, contributed to cur- 


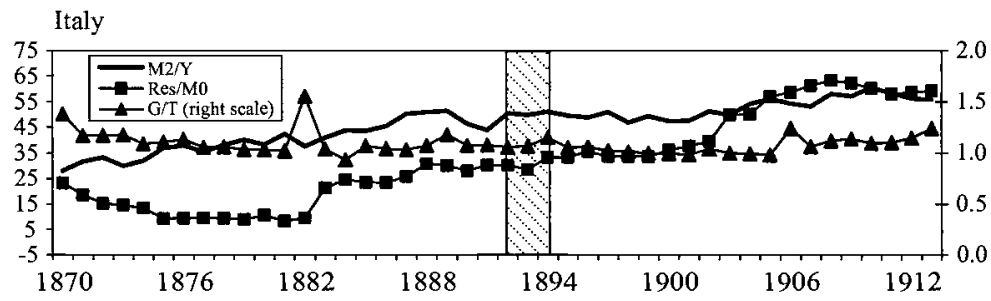

Portugal

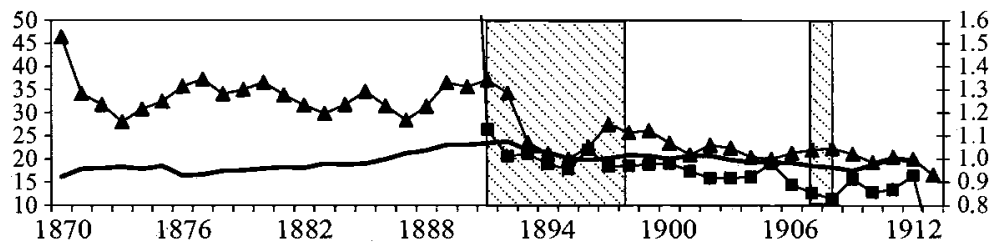

Spain
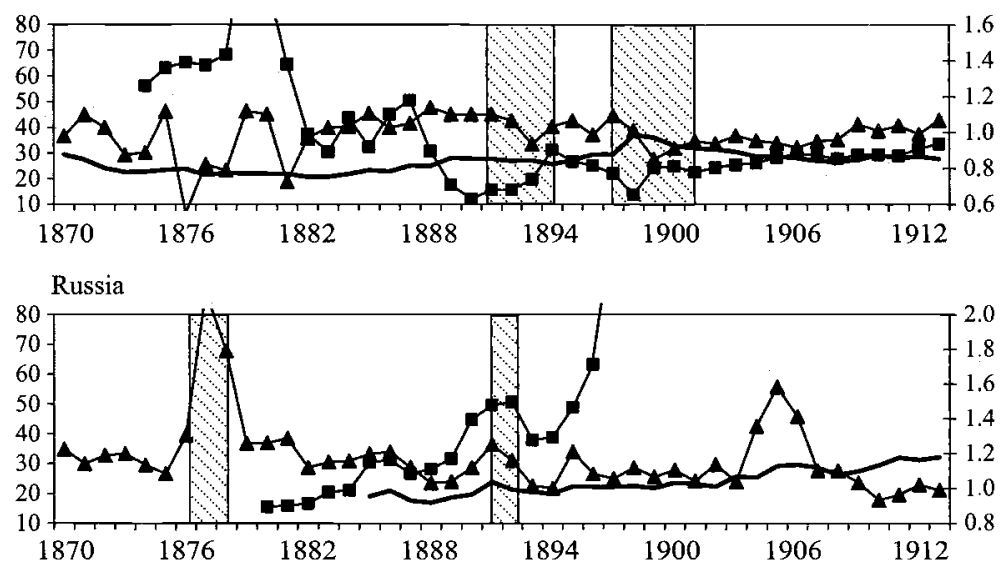

Fig. 7.7 (cont.)

rency crashes: ${ }^{24}$ as with the ratio of broad money to GDP, the money multiplier is noticeably more cyclical in crisis countries than in noncrisis ones.

The other distinguishing feature of countries in which SSs were followed by currency crashes pertains to fiscal behavior. Gauged by either the ratio

24. The focus on M2 rather than on domestic bank credit is motivated by two considerations. One is that theoretical models of nominal exchange rate determination (including the one outlined in appendix 1) commonly postulate a direct link between monetary expansion and the exchange rate. The other is the lack of data on domestic bank credit for several countries. An alternative indicator considered was to derive aggregate bank credit by the difference between broad money and international reserves of the consolidated banking system, using available data on the two variables. This yields a very similar pattern as that of M2. 
Currency Crisis Countries

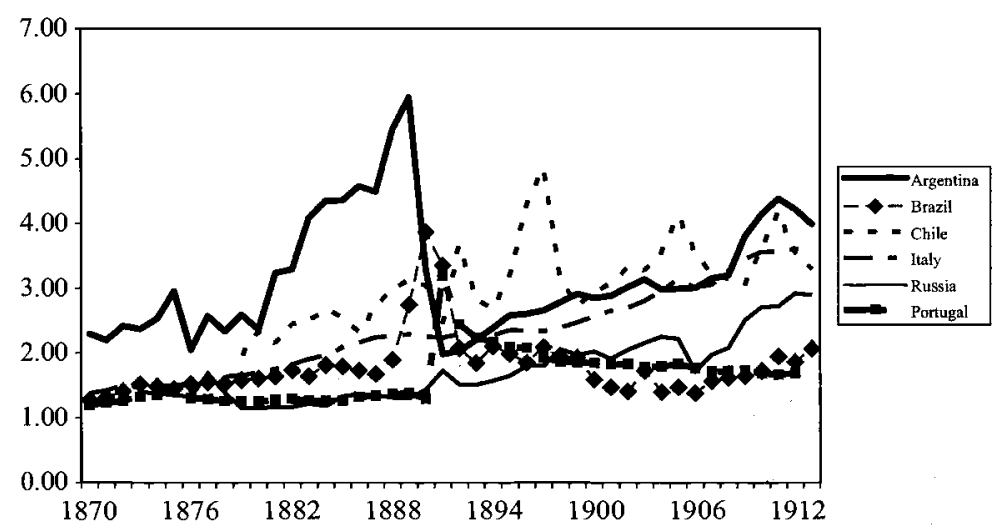

Other Countries

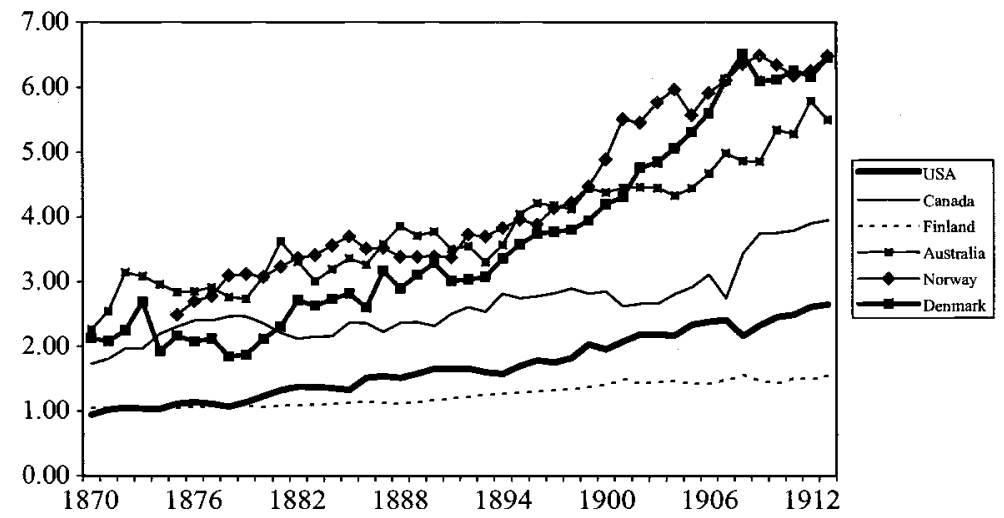

Fig. 7.8 The M2 multiplier

Source: See appendix B.

of public expenditure to revenues or the ratio of public debt to GDP averaged by country over the entire period, it appears that fiscal behavior was generally more relaxed in currency-crash countries. The upper panel of figure 7.9 shows that three of the countries that experienced the worst currency crashes in the pre-WWI era (Argentina, Chile, Greece) were precisely the ones with the highest average ratios of public expenditures to revenues, whereas countries that managed to stick to gold throughout tended to display lower ratios. Clearly there were exceptions, such as Brazil (which experienced large currency drops without strikingly high fiscal imbalances on average), and the association is certainly not one-to-one for all countries (Australia and New Zealand being two other obvious outliers). 
Government Expenditure to Revenue Ratios

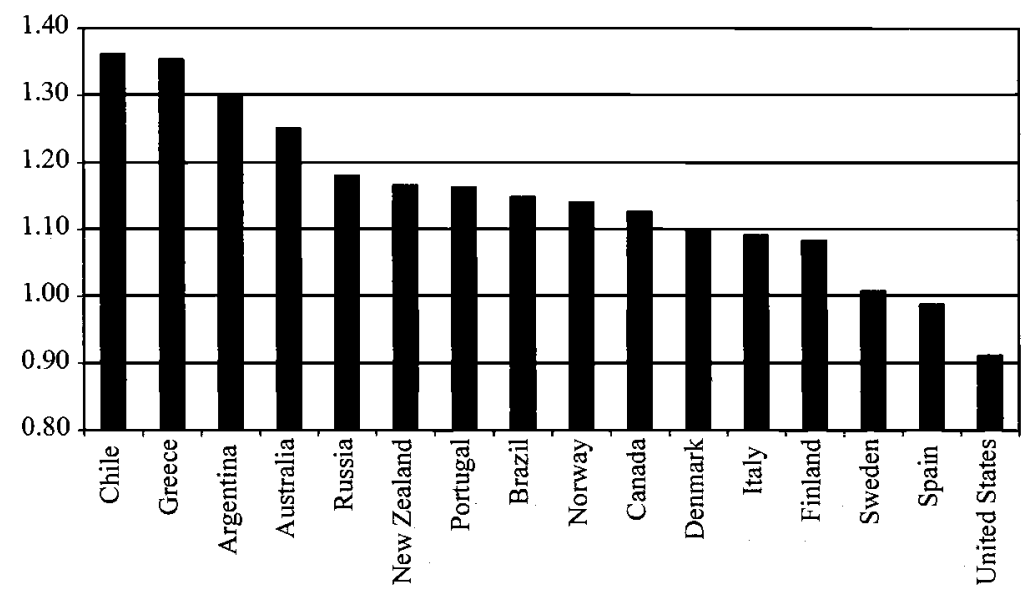

Public Debt to GDP Ratios

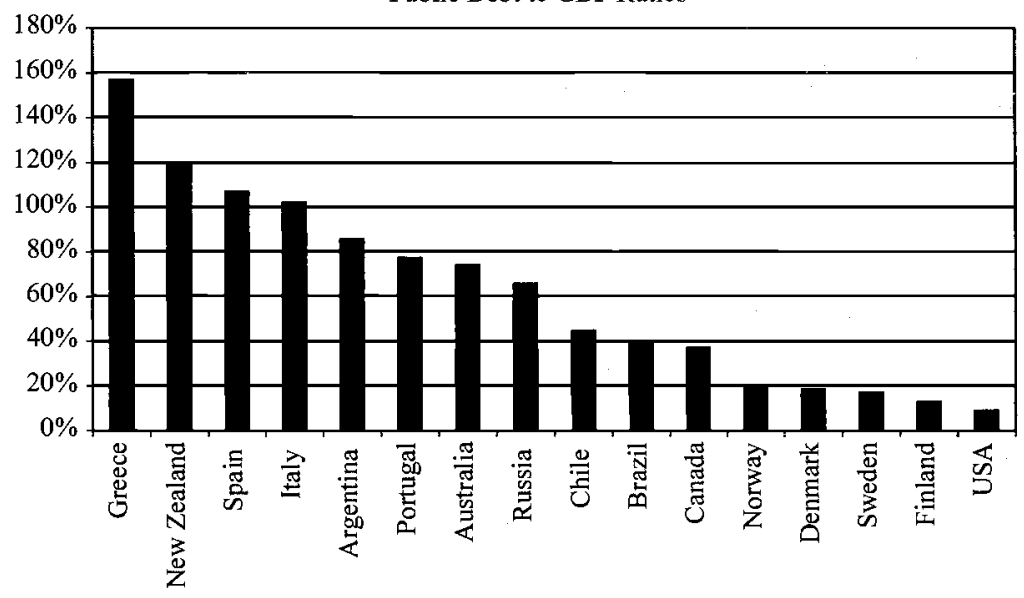

Fig. 7.9 Fiscal indicators: Country averages over 1870-1913

Source: See appendix B.

Overall, the ratio of expenditure to revenues in the currency-crash group was around 10 percent higher than that for the noncrash group. The lower panel of figure 7.9 further reinforces this point: not only did six of the eight noncrash countries lie at the bottom of the debt to GDP distribution over the entire period, but also the average ratio of debt to GDP was twice as high among crash countries ( 85 percent) than among noncrash ones (38 percent).

No less importantly, such period averages obscure the fact that fiscal behavior was more procyclical in currency-crash countries. While there are 
Table 7.3 OLS regression measures of fiscal procyclicality

\begin{tabular}{|c|c|c|c|c|}
\hline & Output gap $_{t}(1)$ & Output gap ${ }_{t-1}(2)$ & Kinflow $\operatorname{gap}_{t}(3)$ & Kinflow gap ${ }_{t-1}(4)$ \\
\hline \multirow[t]{2}{*}{ Argentina } & 1.138 & 1.127 & 0.037 & 0.089 \\
\hline & $(4.46)^{* * *}$ & $(4.33)^{* * *}$ & $(0.60)$ & (1.15) \\
\hline \multirow[t]{2}{*}{ Brazil } & 0.943 & 0.903 & 0.157 & 0.155 \\
\hline & $(6.11)^{* * *}$ & $(5.28)^{* * *}$ & $(2.85)^{* * *}$ & $(2.69)^{* * *}$ \\
\hline \multirow[t]{2}{*}{ Chile } & 1.938 & 1.807 & 0.323 & 0.248 \\
\hline & $(3.55)^{* * *}$ & $(3.21)^{* * *}$ & $(4.02)^{* * *}$ & $(2.76)^{* * *}$ \\
\hline \multirow[t]{2}{*}{ Greece } & 2.284 & 1.930 & 0.050 & -0.029 \\
\hline & $(5.17)^{* * *}$ & $(3.97)^{* * *}$ & $(0.39)$ & $(-0.22)$ \\
\hline \multirow[t]{2}{*}{ Italy } & -0.039 & -0.118 & 0.057 & 0.073 \\
\hline & $(-0.14)$ & $(-0.41)$ & $(1.67)^{*}$ & $(2.08)^{* *}$ \\
\hline \multirow[t]{2}{*}{ Portugal } & 1.097 & 1.090 & 0.030 & 0.047 \\
\hline & $(9.49)^{* * *}$ & $(8.54)^{* * *}$ & $(0.82)$ & $(1.26)$ \\
\hline \multirow[t]{2}{*}{ Spain } & 0.130 & 0.316 & -0.018 & -0.018 \\
\hline & $(0.62)$ & (1.54) & $(-0.71)$ & $(-0.69)$ \\
\hline \multirow[t]{2}{*}{ Russia } & 0.369 & 1.023 & -0.110 & -0.110 \\
\hline & $(0.98)$ & $(3.06)^{* * *}$ & $(-1.96)^{* *}$ & $(-1.89)^{*}$ \\
\hline \multirow[t]{2}{*}{ Australia } & 1.249 & 1.299 & -0.093 & -0.060 \\
\hline & $(6.68)^{* * *}$ & $(7.30)^{* * *}$ & $(-1.47)$ & $(-0.91)$ \\
\hline \multirow[t]{2}{*}{ Canada } & 1.026 & 1.236 & 0.177 & 0.169 \\
\hline & $(4.21)^{* * *}$ & $(5.30)^{* *}$ & $(2.72)^{*}$ & $(2.51)^{* *}$ \\
\hline \multirow[t]{2}{*}{ Denmark } & 0.669 & 0.933 & 0.044 & 0.113 \\
\hline & (1.16) & (1.60) & $(0.84)$ & (2.18) \\
\hline \multirow[t]{2}{*}{ Finland } & 0.235 & 0.227 & 0.054 & 0.039 \\
\hline & $(0.27)$ & $(0.27)$ & $(0.59) * * *$ & $(0.41)$ \\
\hline \multirow[t]{2}{*}{ New Zealand } & 1.571 & 1.687 & 0.052 & -0.006 \\
\hline & $(5.34)^{* * *}$ & $(6.60)^{* * *}$ & $(0.75)$ & $(-0.09)$ \\
\hline \multirow{2}{*}{ Norway } & 0.005 & 1.035 & -0.241 & -0.230 \\
\hline & $(0.01)$ & $(1.48)^{* * *}$ & $(-5.63)^{* * *}$ & $(-5.10)^{* * *}$ \\
\hline \multirow[t]{2}{*}{ Sweden } & -0.043 & 0.098 & 0.040 & 0.034 \\
\hline & $(-0.18)$ & $(0.39)$ & $(1.64)^{*}$ & (1.33) \\
\hline \multirow[t]{2}{*}{ United States } & -0.644 & -0.853 & -0.027 & -0.050 \\
\hline & $(-1.80)^{*}$ & $(-2.54)^{* *}$ & $(-0.62)$ & $(-1.17)$ \\
\hline \multicolumn{5}{|l|}{ Mean } \\
\hline Crash countries & 0.982 & 1.010 & 0.066 & 0.057 \\
\hline Noncrash countries & 0.508 & 0.708 & 0.001 & 0.001 \\
\hline
\end{tabular}

Note: Dependent variable: Real government expenditure cycle.

*** Significant at the 1 percent level.

**Significant at the 5 percent level.

*Significant at the 10 percent level.

different metrics to gauge the degree of fiscal procyclicality across countries (see, e.g., Bayoumi and Eichengreen 1995; Gavin and Perrotti 1997), one measure that mitigates endogeneity issues is that of regressing the cyclical component of real government expenditure on the cyclical component of real GDP and/or foreign capital inflows. As discussed in Kamin- 
sky, Reinhart, and Végh (2004), this is because tax revenues are themselves a direct function of the real GDP cycle - a relationship that is bound to be strong among emerging markets, where tax bases are highly procyclical. This is especially the case during the period under consideration, where import and consumption taxes account for over 80 to 90 percent of tax revenues in most countries comprising our sample (see Bordo and CortesConde 2001 as well as Sokoloff and Zolt's paper in this volume).

The first column of table 7.3 reports the estimated coefficients of a regression of the cyclical component of real government expenditure (as before, measured as deviations from a log linear trend) on the cyclical components of real GDP (also defined as deviations from a log linear trend). While such a regression potentially suffers from well-known biases associated with the use of generated regressors (a downward bias) as well as the potential omission of other explanatory variables (a bias that can go either direction), it is still valuable for the task at hand, which is to highlight crosscountry differences in fiscal reactions to the business cycle. The bivariate regression estimates in the first column of table 7.3 suggest that fiscal policy was highly procyclical in the countries that experienced the worst currency crashes during the period (Argentina, Brazil, Chile, Greece, and Portugal). While there is evidence that the fiscal stance was also procyclical in three other countries that stuck to gold throughout (Australia, Canada, and New Zealand), averages over crash and noncrash groups indicate that the former was about twice more procyclical than the latter ( 0.98 versus 0.51). A similar inference about the higher fiscal procyclicality of the first group of countries also follows when using the one-year lagged instead of current real GDP cycle, as reported in the second column of table 7.3.

In assessing the procyclicality of fiscal policies during this period of free capital mobility, it is also of interest to gauge the extent to which real government expenditure responded to the international cycle in capital flows. More procyclical policy stances should be also associated with a higher elasticity of spending to the supply of external finance. As before, I proxy the latter as the total net capital outflows from the three main capital exports of the late nineteenth century (Britain, France, and Germany), all denominated in sterling (or gold) and measured in terms of deviations from a log-linear trend. The results are reported in columns (3) and (4) in table 7.3. Regardless of whether one uses current or one-year lagged values of the explanatory variable, the group averages reported at the bottom of the table suggest that crash countries tended to display a more responsive fiscal behavior to the push of international capital flows. While the estimated coefficients are not as large nor as statistically significant as before, these regressions again suggest that currency crash countries tended to be more procyclical overall.

Such procyclicality tended to heighten currency risk by inducing looming fiscal imbalances during cyclical upswings. This can be seen in figure 
I. Sudden Stops cum Currency Crashes

Public Expenditure to Revenue ratio (G/T)

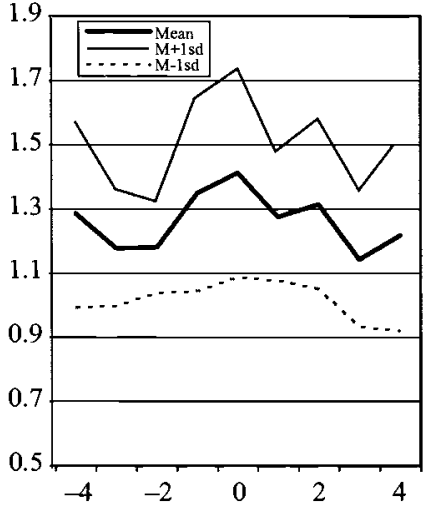

International Reserves to Mo ratio (\%)

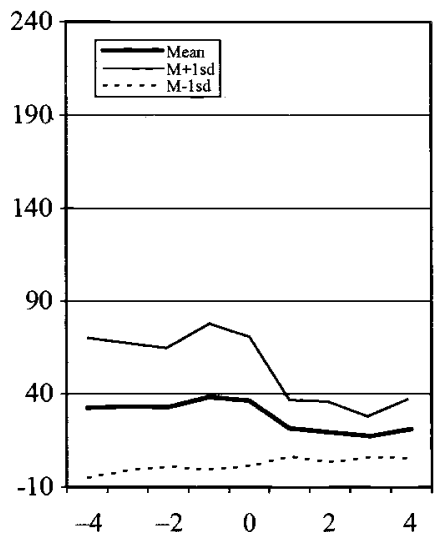

II. Sndden Stops without Currency Crashes

Public Expenditure to Revenue ratio (G/T)

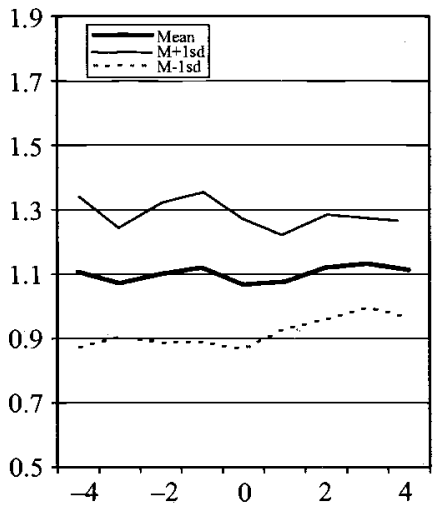

International Reserves to Mo ratio (\%)

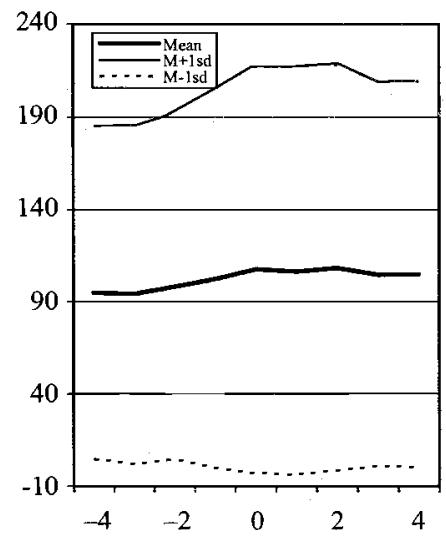

Fig. 7.10 Fiscal and reserve positions around sudden stops Source: See appendix A.

7.10, which contrasts the fiscal behavior (again measured in terms of the ratio of public expenditure to revenues) between currency crash events and noncrash ones. Noting that $t=0$ corresponds to the year immediately before the downturn in capital inflows, it is apparent that fiscal imbalances rose and were much larger, on average, in the subset of countries in which SSs were accompanied by currency crashes. Likewise, the during- and post-shock contrast is no less striking: while the fiscal stance appears to be notably contractionary and hence procyclical among crash countries, noncrash countries engaged in a mildly expansionary - and hence, countercyclical - fiscal behavior. By imparting a further impulse to absorption 
during cyclical upswings, fiscal procyclicality tends to exacerbate imbalances, which in turn will call for a real exchange rate depreciation and/or a sufficiently large drop in absorption. Given the more limited reserve coverage of the monetary base in those countries as well as the presence of nontrivial nominal rigidities even in that earlier period (as discussed in Catão and Solomou 2005), the nominal exchange rate would emerge as a natural candidate to shoulder the burden of the adjustment. Thus, one would thus expect this fiscal expenditure-to-revenue imbalance (G/T gap) to be a significant predictor of currency crashes, and this is precisely what the probit results of table 7.2 show to be the case.

Finally, there is the channel related to the coverage of paper money in circulation (Mo) with hard-currency reserves (mostly gold at the time). The bottom panel of figure 7.10 indicates that, on average, noncrash countries entered the capital inflow cycle with twice as high reserve coverage than their crash-prone counterparts. While the standard error bands are strikingly large for noncrash (reflecting the ratios of bank gold reserves to paper money above 200 percent in the large gold-producing economies of Australia and New Zealand), median comparisons that play down such outliers tell a similar story ( 25 percent versus 56 percent in the year just before the SS). So, the noncrash countries clearly counted on a much larger reserve cushion against the capital account outflow. In addition, the behavior of the reserve coverage ratio during SS events in the noncrash countries suggest that their respective monetary authorities appear to have played more closely by the so-called "rules of the game": absolute reserve losses were accompanied by a roughly concomitant drop in currency in circulation, so that the reserve coverage ratio of Mo remained about stable on average. By contrast, countries with initially lower reserve coverages, and that also missed the opportunity of the boom in capital inflows to prop up their coverage ratios, saw the latter drop by nearly one half (from 38 to 17 percent) between the year preceding the capital inflow peak $(t=-1)$ and the second year after the SS $(t=3)$. To the extent that reserve accumulation is inversely related to fiscal and domestic credit expansion as in firstgeneration currency crisis models a la Krugman (1979), the procyclicality of the domestic fiscal and monetary stances shows up again as a key culprit.

\subsection{Conclusion}

As with the post-Bretton Woods era, international capital flows in the pre-World War I world were anything but smooth. This paper has shown that all net capital-importing countries for which the relevant annual data exist experienced sporadic but often large and abrupt reversals in foreign capital inflows. These sudden stops hit countries with widely disparate per capita GDPs, levels of financial development, and exchange rate regimes, 
as well as countries with low and high gold reserve coverages of their domestic currencies. This suggests that none of these factors can prevent a capital importer from being hit by a large capital account reversal—even though deeper financial markets, exchange rate flexibility, and high levels of precautionary reserves should help mitigate the associated side-effects on economic activity, as the recent literature on SSs indicates (Calvo, Izquierdo, and Mejia 2004; Edwards 2004).

The dataset assembled in this paper also allows us to highlight other striking parallels between SSs now and SSs then. One is the large magnitude of drops in net foreign capital inflows during these episodes, with a median of about 5 percent of GDP (measured peak-to-trough) on a various cross-country basis. The other is the relatively lengthy period it takes for capital inflows to fully recover (four years on average). A third similarity is the time bunching of such events. We have seen earlier that sudden stops bunched around the early to mid-1870s, the early 1890 s, and 19061907. As is well known from the late nineteenth century and early twentieth century economic historiography, all these subperiods were characterized by financial crises and a higher incidence of sovereign defaults (Kindleberger 1978; Lindert and Morton 1989; Kelly 1998; Eichengreen 2003). While in principle these SSs could have been triggered by countryspecific factors in capital importers (such as the U.S. railways bankruptcies of 1873 or Argentina's mortgage bond repayment crisis of early 1890), which then irradiated to other emerging markets, possibly via mechanisms highlighted in the international financial contagion literature (Eichengreen, Rose, and Wyzploz 1996), the evidence provided in this paper points to one common factor in all these events-preceding hikes in central bank discount rates in the core capital exporting countries, typically with a oneto two-year lag. Once again, this has striking parallels with the post-1970 evidence, in that changes in U.S. interest rates appear to be a main driver of capital flows to developing countries (Calvo, Leiderman and Reinhart 1993; Fernandez-Arias 1996) and of shifts in overall emerging market risk (Catão and Kapur 2006). This obviously does not imply that domestic or regional factors (including wars and other political conflicts) have been unimportant during the period in some countries, but simply that monetary tightening in the core of the world economy played a significant role, sometimes reinforcing those country-specific effects.

Against this background, a main question addressed in this chapter is why such SSs led to currency crashes in some countries but not in others. Consistent with the evidence just discussed, the probit regression results of section 7.3 indicate that SSs in capital exports from core countries to the rest of the world, together with lagged international interest rates, did raise the likelihood of currency crises generally, all else constant. But the same regressions also show that country-specific factors related to money growth, reserve coverage of domestic currency, and fiscal imbalances played a no 
less significant role. Countries where money growth was highly responsive to cyclical conditions and grew well in excess of aggregate income and international reserves during upswings were the ones in which the worst currency drops followed. Unsurprisingly, these are countries for which historical literature finds the strongest evidence of a prevalence of loose regulations on banks of issues, institutional obstacles to loan recovery, and high credit elasticity to cyclically sensitive collateral values. Conversely, economies with seemingly better-regulated banks and deeper financial markets typically had a smoother broad money multiplier and also managed to maintain a consistently higher backing of domestic bank liabilities or paper money with international (gold) reserves; they were the ones that managed to overcome the SS shock while sticking to their currency pegs. This evidence brings back to the fore Whale's (1937) and Ford's (1962) earlier views - grounded on a much slimmer data set and limited econometric apparatus - on the importance of the domestic financial imperfections in propagating capital account shocks and accounting for cross-country differences in macroeconomic adjustment during the classic gold standard era.

Similar considerations apply to the role of fiscal policy in affecting currency risk. Countries where fiscal deficits were higher on average and real government spending more procyclical typically witnessed a juxtaposition of SSs and currency drops. The channels through which fiscal imbalances affect the exchange rate are well known from currency crisis literature and, as discussed previously, the probit results are broadly consistent with the prediction of first-generation currency crisis models (Krugman 1979) about the role of fiscal deficits in currency crashes: countries where government expenditures typically grew significantly faster than the tax base during upswings experienced reserve losses and large real exchange rate appreciations that called for sharp correction when capital inflow suddenly dried up. As discussed in Catão and Solomou (2005), nonnegligible nominal rigidities, combined with limits to the necessary decline in absorption and a low elasticity of capital flows to domestic interest rates, implied that the nominal exchange rate would bear much of the burden of adjustment in these cases.

What implications or lessons can be drawn from this evidence? A first lesson is that history often repeats itself, and that the documented patterns of SSs over the past two decades have some striking similarities with those in the past. Thus, they can be regarded as stylized facts about SSs more broadly, and indicate that high capital mobility need not automatically translate into stabilizing cross-border financial flows and greater consumption smoothing. Then, as now, individual countries' capacity to reap benefits and minimize the risk of capital mobility to degenerate into disruptive currency crashes and competitive devaluations lie most critically on fiscal and monetary management and the resilience of countries' domestic banking systems. Those in which the monetary transmission 
mechanism and fiscal policies are more procyclical - be it because of the kind of voracity effects discussed in Tornell and Lane (1998) or other political imperfections (Végh and Talvi 2000) that discourage both public saving and reserve accumulation during good times - are more likely to face greater exchange rate instability and disruptive currency drops as a result.

Two other salient policy implications should also be briefly mentioned. Time bunching in SSs implies that country insurance type of contracts are likely to be more effective, if not only feasible, when drawn between net capital exporters and net capital importing countries, since the latter tend to be badly hit at about the same time, thus limiting the scope for risk sharing among them. Last but not least, to the extent that SSs take place in the wake of monetary tightening in core advanced countries, this suggests that a high international reserve coverage of domestic monetary liabilities when world interest rates start creeping up is an important ingredient in minimizing the risk of abrupt and often contractionary currency drops. This underscores the importance of precautionary reserve accumulation at the earlier upswing stage of the international investment cycle.

\section{Appendix A}

\section{A Benchmark Model of Nominal Exchange Rate Determination}

This appendix briefly outlines a benchmark model of nominal exchange rate determination that guides the empirical analysis of currency crashes provided in the main text. The model assumes that prices are sticky in the short run and that risk-adjusted uncovered interest parity (UIP) holds, so that the expected change in the log of spot exchange rate $\left(\Delta e_{t+1}^{e}\right)$ responds to the nominal short-term interest rate differential between onshore $\left(i_{t}\right)$ and offshore $\left(i_{t}^{*}\right)$ asset markets, adjusted by a time-varying country risk premium $\left(\delta_{t}\right)$ :

$$
\Delta e_{t+1}^{e}=i_{t}^{*}-i_{t}+\gamma \delta_{t}
$$

where positive values for $\Delta e_{t+1}$ denote an appreciation between $t$ and $t+1$, and $0<\gamma \leq 1 .{ }^{25}$ Thus, when the country risk premium rises (or equivalently, foreign finance supply drops), and in the absence of arbitrage failures, a fixed exchange $\left(\Delta e_{t+1}=0\right)$ can only be expected if the short-run domestic interest rate rises relative to the foreign rate. Otherwise, the exchange rate would overshoot at time $t$, depreciating beyond its long-run

25. The risk premium is thus being broadly defined to include bank failure or any confiscation risk that affects the representative asset holding. 
equilibrium (to be defined in the following); only in this case could the home country investor be compensated for the rise in country risk by an expected currency appreciation between $t$ and $t+1$. By the same asset market equilibrium condition, the only way that a rise in the foreign interest rate would be compatible with a fixed exchange rate under unchanged domestic interest rates is if the country risk premium drops: only in this case would equilibrium be maintained without entailing an expected exchange rate change.

In the long run, the exchange rate has to converge to a level that is consistent with good market equilibrium. As is standard in the literature, sticky prices imply that the adjustment process is expected to eliminate differences between actual and equilibrium exchange rate levels gradually:

$$
\Delta e_{t+1}^{e}=-\theta\left(e_{t}-\bar{e}_{t}\right)+E(\Delta \bar{e})_{t} .
$$

where $\bar{e}$ is the log of the long-run equilibrium nominal exchange rate, and $\theta$ characterizes the speed of adjustment, $0<\theta<1$. This implied adjustment dynamics can be shown to be consistent with rational expectations under sticky prices (Frankel 1979).

Combining equations (2) and (3) yields:

$$
e_{t}=\bar{e}_{t}+\frac{1}{\theta}\left[\left(i_{t}-i_{t}^{*}\right)-E\left(\Delta \bar{e}_{t}\right)\right]-\frac{\gamma}{\theta} \delta_{t} .
$$

Equation (4) postulates that at any given point in time the nominal exchange rate moves along its long-run equilibrium level, adjusted upward (downward) by any positive (negative) short-term interest rate differential between home and abroad, a decline (increase) in the country risk premium, and expected changes in the equilibrium nominal exchange rate.

The second pillar of the model hinges on what determines $\bar{e}$. In the long run, PPP may not necessarily hold, so that the equilibrium real exchange rate is possibly time varying:

$$
\overline{r e r}_{t}=\bar{e}_{t}+\bar{p}_{t}^{*}-\bar{p}_{t}
$$

where $p$ and $p^{*}$ are the domestic and foreign price indices, respectively. Using the foreign price as the numeraire and since long-run world price inflation under a gold standard should be negligible, it follows that

$$
\Delta r \bar{e} r_{t}=\Delta \bar{e}_{t}+\Delta \bar{p}_{t} .
$$

Given long-run price flexibility, the standard log-linear version of the Keynes-Hicks money market equilibrium condition allows us to map longrun domestic price inflation onto the behavior of money supply and output aggregates, assuming a log-linear trend in secular velocity:

$$
E(\bar{\pi})_{t}=\Delta \bar{m}_{t}-\phi \Delta \bar{y}_{t}+\vartheta
$$


where $\pi$ is the inflation rate, $y$ and $m$ are the logs of the domestic real output and money stock, respectively; $\vartheta$ is the trend growth rate in money velocity and $\phi>0$.

Substituting equations (5), (6), and (7) into equation (4) yields

$$
e_{t}-\bar{e}_{t}=\frac{1}{\theta}\left[i_{t}-i_{t}^{*}-\gamma \delta_{t}\right]+\frac{1}{\theta} E\left(\Delta \overline{r e r}_{t}\right)-\frac{1}{\theta}\left(\Delta \bar{m}_{t}-\phi \Delta \bar{y}_{t}+\vartheta\right) .
$$

Equalizing long-run to actual values in money and output as is commonly done in empirical applications (see Frankel and Rose 1995), and assuming that expected changes in the real exchange rate are directly proportional to preceding deviations of terms of trade, international productivity differentials, and fiscal positions from their respective longrun trends, this yields

$$
\begin{aligned}
e_{t}-\bar{e}_{t}= & \mu-\frac{1}{\theta}\left(\Delta m_{t}-\phi \Delta y_{t}\right)+\alpha(t o t-\overline{t o t})_{t-1}+\varphi\left(\bar{y}_{p c}-\bar{y}_{p c}^{*}\right)_{t-1} \\
& -\eta\left(\frac{g}{t}-\frac{\bar{g}}{t}\right)_{t-1}+\frac{1}{\theta}\left(i_{t}-i_{t}^{*}\right)-\gamma \delta_{t}+\varepsilon_{t},
\end{aligned}
$$

where $\mu=-\vartheta / \theta$.

The final step is to characterize what determines the country risk premium $\delta$. As in Jeanne and Rose (2002), this is modeled as proportional to the external inflow of liquidity. As discussed in the main text, such an effect is bound to be directly related to the push of capital exports from the core advanced economies $\left(\Delta b^{*}\right)$ net the degree to which domestic authorities or the banking system can offset changes in capital inflows with changes in the foreign exchange reserves to money ratio $(\Delta$ res $)$. This yields the benchmark equation that guides the empirical analysis in the main text:

$$
\begin{aligned}
e_{t}-\bar{e}_{t}= & \mu-\frac{1}{\theta}\left(\Delta m_{t}-\phi y_{t}\right)+\alpha(t o t-\overline{t o t})_{t-1}+\varphi\left(\bar{y}_{p c}-\bar{y}_{p c}^{*}\right)_{t-1} \\
& -\eta\left(\frac{g}{t}-\frac{\bar{g}}{t}\right)_{t-1}+\frac{1}{\theta}\left(i_{t}-i_{t}^{*}\right)+v\left(\Delta b^{*}+\psi \Delta r e s\right)_{t}+\varepsilon_{t}
\end{aligned}
$$

\section{Appendix B}

\section{Data Construction and Sources}

\section{Argentina}

Net foreign capital inflow: Obtained by the difference of changes in specie reserves in domestic banks and the balance on the external current ac- 
count provided in della Paolera, Gerardo and Alan Taylor (2003, data appendix).

Foreign trade and external terms of trade: see Catão and Solomou (2005, appendix 2).

Gold reserves: 1870-1882: bank specie reserves from della Paolera (1992); 1883-1913: della Paolera (1988, 173, col. 3).

Central government expenditures and revenues: Mitchell (2003).

Central government debt: della Paolera and Taylor (2003).

Money: Money in circulation (Mo) from della Paolera (1992). Broad money (M2) computed by splicing the Baiocco's 1870-83 series with that computed by Gerardo della Paolera, both of which reported in della Paolera and Taylor (2003).

Exchange rate: della Paolera and Taylor (2003).

Domestic interest rate: average annual yields on domestic mortgage bonds provided in della Paolera (1988).

Domestic price index: Catão and Solomou (2005).

GDP: della Paolera and Taylor (2003).

Population: Maddison (2003).

\section{Brazil}

Net foreign capital inflow: Franco (1988).

Foreign trade and external terms of trade: IBGE (1986).

Gold reserves: 1870-1900 from Franco (1988); extended through 1913 based on linear interpolation between 1900 and 1905 and using data from Paulo Neuhaus, Rio de Janeiro.

Central government expenditures and revenues: IBGE (1986).

Central government debt: Foreign debt from IBGE. Domestic debt obtained from Levy (1995), "The Brazilian Public Debt-Domestic and Foreign, 1824-1913," in The Public Debt in Latin America in Historical Perspective, ed. Richard Liehr, 209-54. Frankfurt: Vervuert.

Money: Mo and M2 both from IBGE (1986).

Exchange rate: IBGE (1986).

Domestic interest rate: kindly provided by Summerhill and Triner, based on primary data on domestic prices of 5 percent and 6 percent domestic perpetual bonds (polices).

Domestic price index: see Catão and Solomou (2005).

GDP: Contador and Haddad 91975); 1900-13 from C. Haddad (1978).

Population: Maddison (2003).

\section{Chile}

Net foreign capital inflow: derived by difference between changes in specie reserves in the banking system and the external current account balance estimated in Braun et al. (2000).

Foreign trade and external terms of trade: Braun et al. 
Specie reserves: Llona Rodriguez (1990).

Central government expenditures and revenues: Braun et al.

Central government debt: Braun et al.

Money: 1870-78: Mo based on outstanding bank notes from Llona Rodriguez (1990, tables 73 and 75), then spliced with the currency-incirculation series provided in Mitchell (1998). M2 adds total deposits to these series using Llona Rodriguez's estimates, provided in the same source.

Exchange rate: Braun et al.

Domestic interest rate: short-term average loan interest rate charges by domestic banks from Braun et al.

Domestic price index: see Catão and Solomou (2005).

GDP: Braun et al.

Population: Maddison (2003).

\section{Greece}

Net foreign capital inflow: not available.

Foreign trade and external terms of trade: Foreign trade data from Mitchell (2001). Terms of trade series kindly furnished by Jeffrey Williamson.

Specie reserves: Lazaretou (1993).

Central government expenditures and revenues: Mitchell (2001).

Central government debt: Lazaretou (1993).

Money: Lazaretou (1993).

Exchange rate: Catão and Solomou (2005).

Domestic price index: GDP deflator, as provided in Kostelenos et al. (forthcoming).

GDP: Kostelenos et al.

Population: Maddison (2003).

\section{Italy}

Net foreign capital inflow: Calculated as the difference between changes in specie reserves in the banking system and the current account balance reported in Tattara (2000).

Foreign trade and external terms of trade: Foreign trade data from Mitchell (2001), International Historical Statistics: Europe, London. Terms of trade series kindly furnished by Jeffrey Williamson.

Specie reserves: Fratianni and Spinelli (1984).

Central government expenditures and revenues: Mitchell (2001).

Central government debt: Zamagni (1998).

Money: Fratianni, Michele and Franco Spinelli.

Exchange rate: Catão and Solomou (2005).

Domestic price index: Maddison (1991).

GDP: ibid.

Population: Maddison (2003). 


\section{Portugal}

Net foreign capital inflow: not available.

Foreign trade and external terms of trade: Lains (1995). The figures used are based on the author's revision of the respective official series.

Specie reserves: Mata and Valério (1994).

Central government expenditures and revenues: Mitchell (2001).

Central government debt: Mata and Valério.

Money: Fratianni, Michele and Franco Spinelli.

Exchange rate: Catão and Solomou (2005).

Domestic price index: see Catão and Solomou (2005).

GDP: das Neves (1994).

Population: ibid.

\section{Russia}

Net foreign capital inflow: calculated as the difference between changes in specie reserves in the banking system and the current account balance reported in Gregory (1982).

Foreign trade and external terms of trade: export and import values from Mitchell (2000). Terms of trade series kindly provided by Jeffrey Williamson.

Specie reserves: Flandreau and Zulmer (2004).

Central government expenditures and revenues: Mitchell (2001).

Central government debt: Flandreau and Zulmer (2004).

Money: Mo from Crisp (1976, 138-39). M2 adds Mo to bank deposits taken from Mitchell (2001).

Exchange rate: Catão and Solomou (2005).

Domestic price index: see Catão and Solomou (2005).

$G D P$ : in the absence of a GDP series, the net national product estimate provided in Gregory (1982, table 3.1, 56-57), (variant 1) was used.

\section{Spain}

Net foreign capital inflow: unpublished estimates by Leandro Prados, kindly provided by the author.

Foreign trade and external terms of trade: Prados de la Escosura (1988).

Specie reserves: Carreras and Tafunell (1988), and Aceña and Reis (2000).

Central government expenditures and revenues: Mitchell (2001).

Central government debt: Carreras and Tafunell (1988).

Money: Aceña.

Exchange rate: ibid.

Domestic price index: the deflator for private consumption from Prados de la Escosura (2003).

GDP: Prados de la Escosura (2003, Table A.13.5, 681-82).

Population: ibid. 


\section{Australia}

Net foreign capital inflow: calculated as the difference between changes in specie reserves in the banking system and the current account balance underlying Jones and Obstfeld (2001). The database is available at: http:// www.nber.org/databases/jones-obstfeld. The Butlin series was chosen for the estimates reported in this paper, since the new current account estimates which completely exclude gold flows yield surprisingly high absolute levels of net capital inflows to GDP in the early 1890s. Both series yield, however, similar inferences on the timing and magnitude of changes in net capital inflows to GDP.

Foreign trade and external terms of trade: trade values from Mitchell (2002). Terms of trade from Bordo and Rockoff (1996).

Specie reserves: Obstfeld and Jones.

Central government expenditures and revenues: Mitchell.

Central government debt: Obstfeld and Taylor (2003).

Money: Mitchell.

Exchange rate: Obstfeld and Taylor (2003).

Domestic price index: ibid.

GDP: ibid.

Population: Maddison (2003).

\section{Canada}

Net foreign capital inflow: calculated as the difference between changes in specie reserves in the banking system and the current account balance from Urquart and Buckley (1965).

Foreign trade and external terms of trade: trade values from Mitchell (2002). Terms of trade from Urquart and Buckley.

Specie reserves: Obstfeld and Jones.

Central government expenditures and revenues: Mitchell.

Central government debt: Obstfeld and Taylor (2003).

Money: Mitchell (2001).

Exchange rate: Obstfeld and Taylor (2003).

Domestic price index: ibid.

GDP: ibid.

Population: Maddison (2003).

\section{Denmark}

Net foreign capital inflow: calculated as the difference between changes in specie reserves in the banking system and the current account balance underlying Jones and Obstfeld (2001). The database is available at: http:// www.nber.org/databases/jones-obstfeld.

Foreign trade and external terms of trade: trade values from Mitchell (2002). Terms of trade from Andres Olgaard (1993).

Specie reserves: Obstfeld and Jones. 
Central government expenditures and revenues: Mitchell.

Central government debt: Flandreau and Zulmer (2004).

Money: Mitchell.

Exchange rate: Obstfeld and Taylor (2003).

Domestic price index: ibid.

GDP: nominal GDP from Obstfeld and Taylor (2003). Real GDP from

Maddison (2003).

Population: Maddison (2003).

\section{Finland}

Net foreign capital inflow: calculated as the difference between changes in specie reserves in the banking system and the current account balance underlying Jones and Maurice Obstfeld (2001). The database is available at: http://www.nber.org/databases/jones-obstfeld.

Foreign trade and external terms of trade: trade values from Mitchell (2001). Export and import prices, and terms of trade from Hjerppe (1989, 259-60).

Specie reserves: Obstfeld and Jones.

Central government expenditures and revenues: Mitchell.

Central government debt: Flandreau and Zulmer (2004).

Money: Mitchell.

Exchange rate: Obstfeld and Taylor (2003).

Domestic price index: ibid.

GDP: Hjerppe.

Population: Maddison (2003).

\section{New Zealand}

Net foreign capital inflow: not available.

Foreign trade and external terms of trade: Mitchell (2002). Terms of trade kindly provided by Jeffrey Williamson.

Specie reserves: reserves (coins and bullions) in trading banks from Bloomfield (1984, table IX.1, 386-87).

Central government expenditures and revenues: Mitchell.

Central government debt: Obstfeld and Taylor (2003).

Money: sum of currency in circulation from Mitchell and deposits in trading banks from Rankin (1992).

Exchange rate: Obstfeld and Taylor (2003).

Domestic price index: ibid.

GNP: Rankin.

Population: Maddison (2003).

\section{Norway}

Net foreign capital inflow: calculated as the difference between changes in specie reserves in the banking system and the current account balance 
underlying Jones and Obstfeld (2001). The database is available at: http:// www.nber.org/databases/jones-obstfeld.

Foreign trade and external terms of trade: trade values from Mitchell.

Terms of trade from Edison and Klovland (1988).

Specie reserves: Obstfeld and Jones.

Central government expenditures and revenues: Mitchell.

Central government debt: Flandreau and Zulmer (2004).

Money: Mitchell.

Exchange rate: Obstfeld and Taylor (2003).

Domestic price index: Mitchell (2001).

GDP: nominal GDP from Obstfeld and Taylor. Real GDP from Maddison (2003).

Population: Maddison (2003).

\section{Sweden}

Net foreign capital inflow: calculated as the difference between changes in specie reserves in the banking system and the current account balance underlying Jones and Obstfeld (2001). The database is available at: http:// www.nber.org/databases/jones-obstfeld.

Foreign trade and external terms of trade: trade values from Mitchell.

Terms of trade and foreign trade prices from Fridlizius (1963).

Specie reserves: Obstfeld and Jones.

Central government expenditures and revenues: Mitchell.

Central government debt: Flandreau and Zulmer (2004).

Money: Mitchell.

Exchange rate: Obstfeld and Taylor (2003).

Domestic price index: Maddison (1995).

GDP: nominal GDP from Obstfeld and Taylor. Real GDP from Maddison (2003).

Population: Maddison (2003).

\section{United States}

Net foreign capital inflow: calculated as the difference between changes in specie reserves in the banking system and the current account balance underlying Jones and Obstfeld.

Foreign trade and external terms of trade: trade values from Mitchell.

Terms of trade from Williamson (1964, table B4, 262).

Specie reserves: Obstfeld and Jones.

Central government expenditures and revenues: Mitchell.

Central government debt: Obstfeld and Taylor (2003).

Money: Mitchell.

Exchange rate: Officer (2001).

Domestic price index: Balke and Gordon (1989).

GDP: Jones and Obstfeld.

Population: Maddison (2003). 


\section{European Core Countries}

Central bank discount rates: Bank of England's discount rate for Mitchell (1988); Bank of France's discount rate from Lévy-Leboyer and Bourguignon (1985); German discount rate from Homer and Sylla (1991).

Capital exports: U.K. data from Stone (1999); French data from LévyLeboyer and Bourguignon (1985); German data from Bloomfield (1968).

\section{References}

Aceña, Pedro M., and Reis Jaime. 2000. Monetary standards in the periphery, paper, silver and gold, 1854-1933. London: Palgrave Macmillan.

Balke, Nathan S., and Robert J. Gordon. 1989. The estimation of prewar gross national product: Methodology and new evidence. Journal of Political Economy 97:38-92.

Bayoumi, Tamim, and Barry Eichengreen. 1995. Restraining yourself: The implications of fiscal rules for economic stabilization. Staff Papers 42 (1): 32-48.

Blattman, Chris, Jason Hwang, and Jeffrey Williamson. 2003. Terms of trade and economic performance in the periphery 1870-1940. NBER Working Paper no. 9940. Cambridge, MA: National Bureau of Economic Research.

Bloomfield, Arthur. 1968. Patterns of fluctuation in international investment before 1914. Princeton Studies in International Finance no. 21, Princeton University, Department of Economics.

Bloomfield, G. I. 1984. New Zealand: A handbook of historical statistics. Boston: G. K. Hall.

Bordo, Michael, and Roberto Cortes-Conde. 2001. Transferring wealth and power from the old to the new world: Monetary and fiscal institutions in the 17th through the 19th century. New York: Cambridge University Press.

Bordo, Michael, Christopher Meissner, and Angela Redish. 2003. How original sin was overcome: The evolution of external debt denominated in domestic currency in the United States and British dominions. NBER Working Paper no. 9841. Cambridge, MA: National Bureau of Economic Research.

Bordo, Michael, and H. Rockoff. 1996. The gold standard as a "Good Housekeeping Seal of Approval.” Journal of Economic History 56 (2): 384-428.

Braun, Juan, Matías Braun, Ignacio Briones, José Diaz, Rolf Luders, and Gert Wagner. 2000. Economía Chilena 1810-1995: Estadísticas Históricas. Catholic University of Chile, Instituto de Economía, Documento de Trabajo no. 187.

Caballero, Ricardo, Kevin Cowan, and Jonathan Kearns. 2004. Fear of sudden stops: Lessons from Australia and Chile. NBER Working Paper no. 10519. Cambridge, MA: National Bureau of Economic Research.

Calvo, Guillermo, Leonardo Leiderman, and Carmen Reinhart. 1993. Capital inflows and real exchange rate appreciation in Latin America: The role of external factors. IMF Staff Papers 40 (1): 108-51.

Calvo, Guillermo, Alejandro Izquierdo, and Luis Fernando Mejia. 2004. On the empirics of sudden stops: The relevance of balance sheet effects. NBER Working Paper no. 10520. Cambridge, MA: National Bureau of Economic Research.

Cameron, Rondo. 1972. Banking and economic development: Some lessons from history. New York: Oxford University Press. 
Carreras, A., and X. Tafunell, eds. 1988. Estadísticas Históricas de España. Siglos $X I X$ y $X X$. Madrid: Fundación Banco Exterior.

Catão, Luis A. V., and Sandeep Kapur. 2006. Volatility and the debt intolerance paradox. IMF Staff Papers 53 (2): 195-218.

Catão, Luis A. V., and Solomos Solomou. 2005. Effective exchange rates and the classical gold standard adjustment. American Economic Review 94:1259-75.

Contrador, Claudio, and Claudio Haddad. 1975. Produto Real, Moeda e Preços: A Experiência Brasileira no Periodo 1861-1970. Revista Brasileira de Estatística 36 (143): 407-40.

Crisp, Olga. 1976. Studies in the Russian economy before 1914. London: Macmillan. das Neves, João Luís César. 1994. The Portuguese economy: A picture in figures: $X I X$ and $X X$ centuries with long term series. Lisbon: Catholic University.

della Paolera, Geraldo. 1988. How the Argentina economy performed during the international gold standard: A re-examination. PhD diss., University of Chicago.

. 1992. The performance of the Argentine economy during the international gold standard, 1860-1930. Paper presented at the conference Long-Run Economic Growth in Argentina, Brazil and Mexico. London: Institute of Latin American Studies.

- 2003. A new economic history of Argentina. Cambridge: Cambridge University Press.

della Paolera, G., and A. M. Taylor. 2001. Straining at the anchor: The Argentine currency board and the search for macroeconomic stability, 1880-1935. Chicago: National Bureau of Economic Research.

DeLong, B. 1999. Financial crises in the 1890s and the 1990s: Must history repeat? Brookings Papers on Economic Activity 2:253-94.

Dornbusch, Rudiger, Ilan Goldfajn, and Rodrigo Valdes. 1995. Currency crises and collapses. Brookings Papers in Economic Activity 2:221-42.

Edelstein, M. 1982. Overseas investment in the age of high imperialism. New York: Columbia University Press.

Edison, Hali J., and Jan Tore Klovland. 1988. A quantitative reassessment of the purchasing power parity hypothesis: Evidence from Norway and the United Kingdom. Journal of Applied Economics 2:309-33.

Edwards, Sebastian. 1989. Real exchange rates, devaluation and adjustment: Exchange rate policy in developing countries. Cambridge, MA: MIT Press.

. 2004. Thirty years of current account imbalances, current account reversals, and sudden stops. IMF Staff Papers 51 (January).

Eichengreen, Barry. 1992. The gold standard since Alec Ford. In Britain in the international economy 1870-1939, ed. S. N. Broadberry and N. F. R. Crafts, 47-79. Cambridge: Cambridge University Press.

. 2003. Capital flows and crises. Cambridge, MA: MIT Press.

Eichengreen, Barry, and Ricardo Haussman. 1999. Exchange rate regimes and financial fragility. NBER Working Paper no. 7418. Cambridge, MA: National Bureau of Economic Research.

Eichengreen, Barry, Andrew Rose, and Charles Wyzplosz. 1996. Contagious currency crises: First tests. Scandinavian Journal of Economics 98 (4): 463-85.

Fernandez-Arias, Eduardo. 1996. The new wave of private capital inflows: Push or pull? Journal of Development Economics 48:389-418.

Flandreau, Marc, and F. Zulmer. 2004. The making of global finance 1880-1913. Paris: OECD.

Ford, A. G. 1962. The gold standard 1880-1914: Britain and Argentina. Oxford: Clarendon.

Franco, Gustavo H. B. 1988. O Balanco de Pagamentos do Brasil: Novas Estimativas, 1870-1896. PUC Discussion Paper no. 201. Rio de Janeiro. 
1990. A década republicana: Brasil e a economia internacional, 1888-1900. Rio de Janeiro: IPEA.

Frankel, Jeffrey. 1997. On the mark: A theory of floating exchange rates based on real interest differentials. The American Economic Review 69 (4): 610-22.

Frankel, Jeffrey, and Andrew Rose. 1995. A survey of empirical research on nominal exchange rates. In Handbook of international economics, ed. Kenneth Rogoff and Gene Grossman, 1689-1729. Amsterdam: North Holland.

1996. Currency crises in emerging markets: An empirical treatment. Journal of International Economics 41:351-66.

Fratianni, Michele, and Franco Spinelli. 1984. Italy in the gold standard period, 1861-1914. In A retrospective of the classical gold standard 1821-1931, ed. Michael D. Bordo and Anna J. Schwartz, 405-51. Chicago: University of Chicago Press. 1997. A monetary history of Italy. Cambridge: Cambridge University Press.

Fridlizius, Gunnar. 1963. Sweden's exports 1850-1960. Economy and History 2: 38-96.

Fritsch, Winston. 1988. External constraints on economic policy in Brazil, 18891930. Pittsburgh, PA: University of Pittsburgh Press.

Gavin, Michael, and Roberto Perotti. 1997. Fiscal policy in Latin America. NBER Macroeconomics Annual, 11-61. Cambridge, MA: National Bureau of Economic Research.

Goldsmith, Raymond W. 1986. Brasil 1850-1984: Desenvolvimento Financeiro sob um Século de Inflação. São Paulo, Brazil: Harper \& Row.

Gregory, Paul R. 1982. Russian national income, 1885-1913. Cambridge: Cambridge University Press.

Haber, Stephen. 1997. Financial markets and industrial development: A comparative study of governmental regulation, financial innovation, and industrial structure in Brazil and Mexico, 1840-1930. In How Latin America fell behind: Essays in the economic histories of Brazil and Mexico, ed. S. Haber, 146-78. Stanford, CA: Stanford University Press.

Haddad, Claudio. 1978. O Crescimento do Produto Real Brasileiro. Rio de Janeiro: Vargas Foundation.

Hansen, H. 1991. From growth to crisis: The Danish banking system from 1850 to the interwar years. Scandinavian Economic History Review 39 (3): 20-40.

Hjerppe, Riitta. 1989. The Finnish economy, 1860-1985: Growth and structural change. Helsinki: Bank of Finland.

Homer, Sidney, and Richard Sylla. 1991. A history of interest rates. Rutgers, NJ: Rutgers University Press.

IBGE. 1986. Estatisticas Historicas do Brasil. Rio de Janeiro: IBGE.

Jeanne, Olivier, and Andrew Rose. 2002. Noise trading and exchange rate regimes. Quarterly Journal of Economics 117 (2): 537-69.

Jones, Matthew T., and Maurice Obstfeld. 2001. Saving, investment, and gold: A reassessment of historical current account data. In Money, capital mobility, and trade: Essays in honor of Robert A. Mundell, ed. Guillermo A. Calvo, Maurice Obstfeld, and Rudiger Dornbusch, 303-64. Cambridge, MA: MIT Press.

Jonker, Joost. 1997. The alternative road to modernity: Banking and currency, 1814-1914. In A financial history of the Netherlands, ed. M. Hart, J. Jonker, and J. Van Zanden, 94-123. New York: Cambridge University Press.

Jonung, Lars. 1984. Swedish experience under the classical gold standard, 18731913. In The classical gold standard in retrospective, ed. M. D. Bordo and A. Schwartz, 361-99. Chicago: University of Chicago Press.

Kaminsky, Graciela, and Carmen Reinhart. 1999. The twin crises: The cause of banking and balance of payments problems. American Economic Review 89 (3): 473-500. 
Kaminsky, Graciela, Carmen Reinhart, and Carlos Végh. 2004. When it rains it pours: Procyclical capital flows and macroeconomic policies. NBER Working Paper no. 10780. Cambridge, MA: National Bureau of Economic Research.

Kelly, Trish. 1998. Ability and willingness to pay in the age of the pax Britannica. Explorations in Economic History 35:31-58.

Kindleberger, Charles P. 1978. Manias, panics, and crashes. New York: Macmillan.

Kiyotaki, N., and J. Moore. 1997. Credit cycles. Journal of Political Economy 105 (2): 211-48.

Kostelenos, G., S. Petmezas, D. Vasileiou, E. Kounaris, and M. Sfakianakis. Forthcoming. Gross domestic product 1830-1939, sources of economic history of modern Greece, quantitative data and statistical series 1830-1939. Athens: Historical Archives of the National Bank of Greece.

Krugman, Paul. 1979. A model of balance of payments crisis. Journal of Money, Credit and Banking 11:311-25.

Lains, Pedro. 1995. A Economia Portuguesa no Século XIX. Crescimento Económico e Comércio Externo. Lisbon: Imprensa Nacional.

Lazaretou, Sophia. 1993. Monetary and fiscal policies in Greece: 1833-1914. Journal of European Economic History 22 (2): 285-311.

Levy, Maria Barbara. 1995. The Brazilian public debt-domestic and foreign, 1824-1913. In The public debt in Latin America in historical perspective, ed. Reinhard Liehr, 209-54. Frankfurt: Vervuert.

Lévy-Leboyer, M., and François Bourguignon. 1985. L'Economie Français au XIX $X^{e}$ Siécle. Paris: Éditions Économica.

Lindert, Peter. 1969. Key currencies and gold, 1900-1913. Princeton Studies in International Finance no. 24. Princeton University, Department of Economics.

Lindert, Peter, and Peter Morton. 1989. How sovereign debt has worked. In Developing country debt and economic performance, ed. Jeffrey Sachs, 225-35. Chicago: National Bureau of Economic Research.

Llona Rodriguez, Agustin. 1990. Chilean monetary policy: 1860-1925. PhD diss., Boston University.

. 2000. Chile during the gold standard: A successful paper money experience. In Monetary standards in the periphery: Paper, silver and gold, 1854-1933, ed. P. M. Acena and J. Reis, London: Macmillan.

Maddison, Angus. 1991. Dynamic forces in capitalist development. Oxford: Oxford University Press.

. 2003. The world economy: Historical statistics. Paris: OECD.

Mata, Maria Eugénia, and Nuno Valério. 1994. História Económica de Portugal. Lisbon: Presenca.

Mauro, Paolo, Nathan Sussman, and Yishay Yafeh. 2002. Emerging market spreads: Then versus now. Quarterly Journal of Economics 117 (2): 695-733.

Meissner, Christopher. 2005. A new world order: Explaining the international diffusion of the gold standard, 1870-1913. Journal of International Economics 66:385-406.

Milesi-Ferretti, Gian Maria and Assaf Razin. 2000. Current account reversals and currency crises: Empirical regularities. In Currency crises, ed. P. Krugman, Chicago: University of Chicago Press.

Mitchell, Brian. 1988. British historical statistics. Cambridge: University of Cambridge Press. millan.

2001. International historical statistics: Europe, 1750-1993. London: Mac. 2002. International historical statistics: Asia and Oceania. London: Macmillan. 
2003. International historical statistics: The Americas, 1750-1993. London: Palgrave Macmillan.

Obstfeld, Maurice, and Kenneth Rogoff. 1996. Foundations of international macroeconomics. Cambridge, MA: MIT Press.

Obstfeld, Maurice, and Taylor, Alan M. 2003. Sovereign risk, credibility and the gold standard: 1870-1913 versus 1925-31. Economic Journal 113 (487): 241-75. 2004. Global capital markets: Integration, crisis, and growth. Cambridge:

Officer, Lawrence H. 2001. Exchange rate between the United States dollar and the British pound, 1791-2000: Source notes. Economic History Services. http:// www.eh.net/hmit/exchangerates/poundsource.html

Olgaard, Andres. 1993. The Danish terms of trade in foreign trade, 1875-1963. In The economic development of Denmark and Norway since 1870, ed. Karl Gunnar Persson. Hants, England: E. Elgar.

Prados de la Escosura, Leandro. 1988. De impirio a nación. Crecimiento y atraso económico en España (1780-1930). Madrid: Alianza.

. 2003. El progreso economico de España, 1850-2000. Madrid: Fundacion BBVA.

Reis, Jaime. 2000. The gold standard in Portugal 1854-91. In Monetary standards in the periphery: Paper, silver and gold, 1854-1933, ed. P. M. Aceña and Jaime Reis, 69-111. London: Macmillan.

Stone, Irving. 1999. The global export of capital from Great Britain, 1865-1914. London: Macmillan.

Tattara, Giuseppe. 2000. Was Italy ever on gold? In Monetary standards in the periphery: Paper, silver and gold, 1854-1933, ed. P. M. Aceña and Jaime Reis, 1868. London: Macmillan.

Tornell, Aaron, and Philip Lane. 1998. Are windfalls a curse?: A nonrepresentative agent model of the current account. Journal of International Economics 44 (1): 83-112.

Triner, Gail. 2000. Banking and economic development: Brazil, 1889-1930. New York: Palgrave.

Urquart, M. C., and Kenneth H. A. Buckley. 1965. Historical statistics of Canada. Cambridge: University of Cambridge Press.

Végh, Carlos, and Ernesto Talvi. 2000. Tax base variability and procyclical fiscal policy. NBER Working Paper no. 7499. Cambridge, MA: National Bureau of Economic Research.

Whale, P. B. 1937. The working of the prewar gold standard. Economica 18-32.

Williamson, Jeffrey G. 1964. American growth and the balance of payments 18201913. Chapel Hill: University of North Carolina Press.

Zamagni, Vera. 1998. Il Debito Pubblico Italiano 1861-1946: Riconstruzione della serie storica. Rivista di Storia Economica 14:207-42. 
